Portland State University

PDXScholar

1977

\title{
Social Profile of the Portland-Vancouver Metropolitan Area
}

Terry L. Cross

Portland State University

Follow this and additional works at: https://pdxscholar.library.pdx.edu/open_access_etds

Part of the Social Work Commons

Let us know how access to this document benefits you.

\section{Recommended Citation}

Cross, Terry L., "Social Profile of the Portland-Vancouver Metropolitan Area" (1977). Dissertations and Theses. Paper 1897.

https://doi.org/10.15760/etd.1896

This Thesis is brought to you for free and open access. It has been accepted for inclusion in Dissertations and Theses by an authorized administrator of PDXScholar. Please contact us if we can make this document more accessible: pdxscholar@pdx.edu. 
SOCIAL PROFILE OF THE PORTLAND-VANCOUVER

METROPOLITAN AREA

\section{by}

TERRY L. CROSS

A report submitted in partial fulfillment of the requirements for the degree of

MASTER OF

SOCIAI WORK

Portland State University

1977 
The research practicum which follows was completed as a Western Interstate Commission for Higher Education Intern Report for the U. S. Army Corps of Engineers, Portland District. 


\title{
SOCIAL PROFILE \\ OF THE \\ PORTIAND-VANCOUVER METROPOLITAN AREA
}

BY

TERRY L. CROSS

\author{
PROJECT COMMITTEE \\ DR. FRANK MILES \\ RUTH LOVE \\ PAUL WILSON \\ SUSAN BAILEY
}

SEPTEMBER 1976 
Methodology- Portland-Vancouver Overview

Willamette River Communities- 8

Urban Fringe-- 16

Outlying Towns- 24

Rural-

Vancouver- 38

The City of Portland- 44

Southeast Portland- 45

Northeast Portland-_ 51

North Portland- 57

Northwest Portland- 62

Southwest Portland- 67

Land Use--

Citizen Participation- 73

Conclusions-2. 74

Recommendations-10 75

Appendix I - Maps- 77

Appendix II - Resources- 84

Appendix III - Interview Topic Schedule

Selected Bibliography 87 
This report is the compilation of data gathered from interviews with informed community leaders and members and from the 1970 Census of Population and Housing. It draws from this information a feeling for the Portland-Vancouver area concerning its people, its issues, and concerns. This attempt to get to know the Metro area found much concern over the issue of land use; a growing awareness and use of citizen participation; a strong sense of individualism; and rapid growth with resulting social problems.

The author suggests the report be read in its entirety. However, for one wishing to concentrate on only one of the ten profile areas, the author suggests reading the methodology, the specific section; the comments on land use and citizen participation; and the conclusions: One should keep in mind that the narratives are impressions of the community. 


\section{INTRODUCTION}

The objective of this research is to provide the Portland District Corps of Engineers Urban Studies team with a written statement from which planners can begin to determine the social factors, for any given section of the Metro area, which should be taken into account in planning. This project, along with other profiles and studies, will provide the Urban Studies team with a broad base of information.

In the Corps of Engineers, as in many other Federal agencies, identification and analysis of social impacts has become a required part of the planning process.1/ In order that such studies can be properly done, it is necessary to first collect a base of information about an area and secnid, to attempt to predict those social factors which are likely to experience some impact from a given alternative plan. This procedure aids the Corps in determining the focus for social impact studies. This profile is intended to provide a resource of summarized social information concerning the Portland-Vancouver Metropolitan area to be used in the afore-mentioned process.

The Portland-Vancouver Metropolitan area is considered to include Washington, Multnomah, and Clackamas counties, plus southwestern Columbia County in Oregon and Clark County in Washington.

\section{Statement of Objectives}

The objective of this research study is to identify the Metro area in such a manner as to give planning personnel a composite picture of the area. Such a picture should not only give physical and statistical data but should also provide a feeling for the area and its parts. The reader of this report should be able to perceive from it the conscience of the comiunity. It should show strengths and weaknesses of the communities, methods of solving problems, intra- and inter-community relationships and roles and community identity. It should be concerned with how well the community (and subparts) meets those needs which bring people into a community relationship. The project should attempt to identify norms, values, attitudes, and emotional climate. It should, by examining the parts, give a picture of the whole.

1/ Water Resources Council, "Principles and Standards for Planning Water and Related Resources," effective October 25, 1973, and implementing regulations. 
Specific tasks necessary to accomplish the project objectives follow (not necessarily in order of priority): *

1. To identify the unit and subunits.

2. Secure a brief historical perspective of unit and parts.

3. Identify existing stresses on the community.

4. Identify existing strengths and weaknesses.

5. Identify problem solving competence, i. e., coping mechanisms and their effectiveness.

6. Define community personality, i. e., physical, intellectual, emotional, and social functioning, identity, cohesiveness, morale, solidarity, etc.

7. Define and identify socioeconomic levels, the community roles as a part of the larger unit.

8. Explore community membership (ethnic, political, educational, subcultures, and their integration).

9. Identify inter- and intra-community relationships, i.e., governments and mobility.

\section{Methodology}

Major concerns in this study were the time and manpower constraints. The study was designated as a 12 -week project to be completed by one intern. The study area is spread over 4,000 square miles of the most populated area of oregon. The design of the project is aimed at maintaining a broad scope while keeping the project manageable.

The design of this research has both exploratory and descriptive elements. The descriptive portion of the design attempts to portray briefly the socioeconomic, occupational, and educational characteristics of the population, using 1970 census data. While there are several drawbacks to the use of Census material, such as the age of the data and sampling techniques, this data is felt to be the best, most practical, and of the most uniform availability to generally indicate population characteristics. It is presented in the form of graphic illustrations and a brief summary for each of the areas profiled.

The 1970 census was conducted primarily through self-enumeration. $2 /$ Census questionnaires were mailed out to about three-fifths of the nation's population to be completed and mailed back. Incomplete and inconsistent forms were followed up with personal contacts and phone calls. The remaining two-fifths of the population were contacted in person. Three types of questionnaires were used. Eighty percent of the households answered a questionnaire with a very limited number of population and

2/ 1970 Census Data-Collection Procedures. Urban Atlas: Tract data for Standard Metropolitan Statistical Areas. Portland, Oregon Washington, P. 1 
housing questions. The remainder, split into 15-percent and 5-percent samples, received a more complete questionnaire. A random procedure was used to determine which of the three questionnaires any particular household answered.

The purpose of the illustrations is to organize pertinent information in such a way that a pattern emerge which facilitates comparisons among the subareas. The direction of the connecting lines is not significant, but a continuous line helps establish a visible profile. The range of scores in each profile area is indicated by the shaded area of the graph. For each of the ten profile areas ten variables are plotted.

Available descriptive information concerning local government, community services and resources, and history has been included in the narrative descriptions of the communities.

The main focus of this project is the exploratory portion. Because relatively little of the existing knowledge and impressions concerning the Metro area has been written down, this project relies on an experience survey to gain insight into the area. A series of personal interviews gathered what those interviewed felt to be facts concerning the areas with which they were familiar. The results of such interviews have been written into narrative form. These narratives are meant to be descriptive impressions. They are not intended to be read as factual conclusions.

Because of the time and manpower constraints, it was necessary to carefully choose respondents for their experience and ability to articulate that experience. Selection was based on a word-of-mouth search for individuals considered to be knowledgeable and informally sanctioned as spokespersons for the various communities. A total of 63 interviews was held and an attempt was made to ensure representation of different perspectives on the communities. Community leaders from business, education, social services, government, professions, neighborhood organizations, and civic groups were included, as well as persons from all age groups.

The interview technique used was a topical discussion. This method was selected to allow flexibility. A few early interviews were also used as direction finders, to help define the scope of the project and refine the topical outline used in the interviewing process.

Difficulties with this type of data gathering include getting an adequate sample, discussing fruitful topics, and assimilating data so gathered into a meaningful narrative. These drawbacks are more than overcome by the value of information gathered.

Divisions of the area

The area has been divided into two main parts, the city of Portland and that part of the study area outside of the city of Portland. 
The city has been divided into five geographic sectors: North, Northeast, Southeast, Southwest, and Northwest. Burnside Street generally divides the city north and south, while the Willamette River divides the city east and west. Groupings used in this report are those used by the neighborhoods in defining themselves, rather than strict geographical definitions. Therefore, those east side neighborhoods between Burnside and the Banfield Freeway are considered as Southeast, and the Goosehollow neighborhood is considered as part of Northwest. North Portland is that area between the Willamette River and N. Williams Avenue.

The study area outside the city limits is also divided into five areas of a focus. Those areas are: (1) the Willamette River towns, (2) the urban fringe, (3) the city of Vancouver, Washington and its urban fringe, (4) outlying towns, and (5) rural.

The division of the study area is based on consultations and recommendations taken in the early design of this project. The use of maps and aerial photographs at differing scales and on-sight observations were also very useful in designing the division of the area. Each division was selected so as to have certain common attributes which set it apart as an identifiable entity.

Within the city of Portland three neighborhoods in each sector are examined. This procedure was followed because of the large number of neighborhoods and the wide range of conditions which exist between neighborhoods. Neighborhoods were selected based on consultations plus criteria such as income and location, which point up the range of different conditions. It is intended that examination of the range within each sector will generally profile that sector.

Subareas - Definitions and list of communities included

1. Willamette Valley Towns - those cities and towns south of the Portland city limits along the Willamette River. The following communities are included:
Wilsonville
Glads tone
West Linn
Milwaukie
Oregon Cịty
Lake Oswego

Oak Grove area

2. Urban Fringe - those urbanized areas contiguous to the city of Portland but not necessarily each other. (Urbanized area refers to incorporated and non-incorporated places with a population. density of 1,000 or more inhabitants per square mile.) Beaverton, Tigard, Gresham, Troutdale, Tualatin, Durham, King City, and Wood Village are the Urban Fringe communities considered.

3. Vancouver: the city of Vancouver plus its urban fringe. 
4. Outlying towns: incorporated towns with a population of 1,000 to 10,000 people outside the urban and urban fringe areas. Included are:

Oregon

Washington

Clackamas Co. Canby Molalla

Sandy

Estacada

Washington Co. Hillsboro

Cornelius

Forest Grove

Sherwood

$\begin{array}{cl} & \text { Washington } \\ \text { Columbia Co. } & \text { Clark Co. } \\ \text { St. Helens } & \text { Camas } \\ \text { Scappoose } & \text { Washougal } \\ & \text { Battleground }\end{array}$

5. Rura1: all areas outside Portland and other designated subareas including towns with under 1,000 population.

6. Portland: That area enclosed by the city limits of Portland, Oregon and broken down into five divisions, i.e., N.E., S.E., S.W., N.W., N. 
PORTIAND - VANCOUVER

OVERVIEW

The study area of this project is the Portland-Vancouver Metropolitan area, located about 100 miles inland from the Pacific Ocean. The geography of the area is characterized by a large north-south river valley, bordered to the east and west by mountains. The city of Portland is located at the north end of this valley, at the confluence of the Willamette and Columbia Rivers. The Washington-Oregon border follows the Columbia River. To the east the Cascade Mountain Range-and impressive Mt. Hood overlook the metropolitan area. To the west lies the Coast Range. The Tualatin Mountains extend southeast from the Coast Range along the Columbia and Willamette Rivers and into the city, creating the area commonly referred to as the West Hills. Elevation in the study area ranges from about 24 feet along the Columbia River to 11,235 feet at Mt. Hood. The study area covers about 4,000 square miles and includes 5 counties. The total population of the project area is over $1,100,000 \cdot \underline{3} /$

The area is served by water, rail, air and highway transportation, each serving a sector of the economy. The Ports of Portland and Vancouver are among the busiest on the West Coast. Portland Harbor was visited by 1,428 vessels in 1973. 4/ Historically the waterways and natural resources have been an important part of the quality of life in Oregon.

The Portland Metropolitan area was once inhabited by Indian tribes. These native peoples used the rivers for transportation and fishing. They hunted and gathered roots and berries in the lush forests. Not until the early 1800's did the white man approach the area in any numbers. First an attraction because of the rich fur supply and trade with the Indians, the area's value as a trade center soon grew. Early settlements at Fort Vancouver, Oregon City, and Portland prospered as the great stands of timber became important to the area's economy. The Great Oregon Migration brought hundreds of settlers into the Willamette Valley. This time the attraction was the rich and fertile farm lands. The combination of abundant natural resources, access to water transportation and power, and the aesthetic beauty of the area continue to make it a natural center for commerce, shipping, industry, and recreation.

3/ Office of the Secretary of State, Oregon Blue Book 1975-76 (Salem, Oregon) pp. 190-205.

4/ Oregon Blue Book 1975-76, p. 48 
Today the Metro area's economy and liveability still center around lumber, agriculture, and water. Manufacturing is mostly of wood and wood-related products, but other manufacturing including food processing, electronic equipment, sports clothes, and aluminum are important parts of the economy.

In summary, this region is one of the most liveable places in the country. It is experiencing rapid growth because of its attractive qualities and expanding economy. Few areas of the country appear to have as much going for them. 
PROFILE NO. 1

THE WILIAMETTE RIVER COMMUNITIES

\section{Overview:}

The Willamette River Communities area is that study area which includes those communities south of the city of Portland along the Willamette River. It includes the incorporated cities of Milwaukie, Gladstone, Oregon City, Lake Oswego, West Linn, and Wilsonville, plus a nonincorporated area between Gladstone and Milwaukie known as the Oak Grove-Jennings Lodge area. Together these communities comprise an area not ordinarily defined as a region but which has commonalities setting it apart as a distinct area. These communities make up most of the urban portion of Clackamas County, the third most populated county in Oregon. The area's history as one of the first settled and incorporated areas of the northwest has helped identify it as independent from the city of Portland. Its principal industries are centered around light manufacturing, lumber and wood products, and warehousing. The area has good access to water, rail, and highway transportation and has an adequate work force. Over 200 firms are located here.

Both public and private schools are available. North Clackamas School District No. 12 includes a separate vocational training center. Clackamas County Community College located in Oregon City has an enrollment of 12,166 .

Social services are provided by both public and private agencies. Local governments seldom provide these services as they are provided at the county, state, and private levels. Access to services is available in most communities but primarily in Oregon City, which is the county seat.

Health services are available at Dwyer General Hospital in Milwaukie, Oregon City Hospital in Oregon City, Meridian Park Hospital in Lake Oswego, the Kaiser Foundation Hospital east of Milwaukie, and at facilities located elsewhere in the metro area.

There are churches of nearly every denomination in the area, predominantly Protestant.

The media from the larger Metro Area, as well as local publications, serve this area. The Milwaukie Review, The Lake Oswego Review, and The Enterprise Courier (Oregon City) provide residents with local news and provide a stimulus for community action.

The following material is; based on interviews in which respondents gave their impressions concerning their area. 
Milwaukie:

Milwaukie is the northernmost community of the river towns. It borders the city of Portland on the north with no visible division between the cities. This lends itself to the common feeling that Milwaukie is merely a residential extension of the city of Portland with little identity of its own. On closer examination, one finds a relatively well-rounded community. It has many strengths. A relatively large amount of industry is served by an efficient and accessible transportation system. It is felt to have a strong city government, with a good degree of citizen participation. The local paper reflects citizens' concern with what is happening, and local government seems to be responsive. Citizen participation comes in the form of neighborhood groups, voter turnout, and personal appeals to local officials. There is also a degree of community self-support, of neighbor relying on neighbor. This is informal and social services are left to county, state, and private agencies.

Milwaukie is one of the fastest-growing areas in the Metro area with a population of about 18,030 . This rapid growth has brought many problems, and it is the problems associated with growth that people are concerned with. Land use, education, taxes, transportation, and planining are all very important issues to the people of Milwaukie. While the people are not anti-growth, they see problems created by rapid growth and are making efforts to slow growth in order to be able to plan.

The people'making up Milwaukie's population are quite varied. The town is sometimes characterized as blue collar but actually has a mixture of wage earners and salaried workers. There are no real pockets of high income families. There are a few sections of lower income families but no distinct areas one would call ghettos. The education level seems to be mixed while family income is relatively homogeneous. There is a feeling of cautious optimism about the area because of its potential for growth and the needs that growth will bring.

The role of Milwaukie in the Metro Area is probably that of a residential or bedroom community, but to much less an extent than is normally assumed. Its identity as a community is stronger than often thought; it was suggested that perhaps the place where people own property, no matter if they shop there or work there, is the place where their greatest personal interest lies. Its heterogeneous population is active in government in the best Oregon tradition and is sophisticated in approach to problems.

\section{Gladstone:}

Gladstone is bordered by the Willamette and Clackamas Rivers and by the nonincorporated area to the north. Gladstone is less than half the size of Milwaukie, with a population of about 8,000 . It is very different from Milwaukie in that there is little industry and commerce. It fits the description of being residential. However, its people work in Oregon City, 
Milwaukie, and Portland, and thus it is not necessarily a bedroom community of the city of Portland.

In contrast to Milwaukie, citizen participation is lower, a feeling of apathy is apparent, and the problems of growth do not seem to be as immediately threatening as in Milwaukie.

Like Milwaukie, the population of Gladstone is a mixed group of white collar and blue collar. The families in Gladstone are predominatnly middle to low-middle income.

\section{Oregon City:}

Oregon City is probably the most identifiably separate community of the river towns, partly because of its geographic location and historic quality. The city of 12,000 is located on the east side of the willamette and south side of the Clackamas River. It was first incorporated city west of the Rocky Mountains, the first capital of the Oregon territory, and site of its first legislative session. This tradition helps give Oregon City what respondents felt is an identity of its own.

Oregon City is the least likely of the river towns to be called a bedroom community. It has industry, with good access to transportation; it has a downtown commercial district with a strong small town atmosphere; and it is the county seat of Clackamas County and has many county office facilities.

Oregon City also has its own hospital and community college and lacks only a facility for cultural events. Much more a blue collar town, Oregon City gives the feeling of being a commercial center for the rural areas around it. It thus has a somewhat rural tone in its government and people. In Oregon City there is less perception of threat from growth, and while planning is an issue, there is not the degree of urgency and citizen participation found in Milwaukie. Citizen participation is centered around the history of Oregon City and personal-social interests rather than other issues.

\section{Lake Oswego:}

Lake Oswego is the largest of the river towns in terms of population with about 19,000 people. Like Oregon City, it has historical and geographic characteristics which separate it from the rest of the Metro Area. Bordered by the river on the east and lightly populated areas a11 around, there is a definite feeling of leaving the city of Portland and then entering the city of Lake Oswego. The city began because of the availability of water transportation and power. Water is still the main theme of the community, but today it is for recreation and beauty as we11 as power. 
Lake Oswego has long been stereotyped as the affluent Portland suburb. This is somewhat true as is indicated by the census data but is much less true than is ordinarily thought.

The most outstanding characteristic of Lake Oswego is its citizen participation. With some of the best citizen participation in the nation, the city has moved far ahead in land use planning and related areas. With the use of citizen volunteers, neighborhood groups have formed and a history, surveys, and numerous resource inventories have been compiled. The local newspaper and schools also reflect this spirit of community involvement.

Lake Oswego has been supportive of regional government and has been proplanning.

More than any of the other areas, Lake Oswego is felt to be a bedroom community of Portland. There is little industry, and its population is heavily white collar with middle to upper income. Social services are left to the county, state, and private agencies. There are few consumers of these services in Lake Oswego. Those of lower income and the elderly are moving out or not moving in because of the high cost of property and rent.

Like Milwaukie, the main issues are those around too rapid growth and the problems it brings. The mood is optimistic with regard to the community's ability to plan, but the planning was brought about by a basic pessimism around the threat of growth.

West Linn:

West Linn's population of about 8,600 is located south of Lake Oswego along the west bank of the Willamette River. It was incorporated at about the same time as Lake Oswego but is quite different. The geography of West Linn has separated it into at least three divisions, and no real town center has evolved. Although it, like Oregon City, is surrounded by rural area, it' does not have the same small town commercial atmosphere. It is apparent that most of the population work and shop outside of the area.

The three areas which make up the city have different population groups, one blue collar, another mixed, and one mainly white collar. This situation has "reportedly created difficulty in uniting the city on any project.

Although the city lacks a sense of being a single community, it has many strengths. West Iinn is proud of its school district, its library, and co'munity education programs. It is described as a pleasant, calm, residential area with few major issues. One does not get the feeling that growth and related problems have as yet had as great an impact on the people of West Linn as some of the other cities. There is growing concern over water and sewer districts, recreation, taxes, and other 
growth problems, but the people have not come together as a community to deal with them.

Citizen participation takes a different form in West Linn. People reportedly serve very well when asked to do so but seldom organize themselves. Members of the community have tried to organize and bring together the three parts of the city but with little success. The citizens' groups which exist are within each separate division.

The city government, progressive but cautious, is thought to be responsive to people's needs when it can find a consensus and set priorities. The city's role in the larger Metro Area is primarily as a residential area.

\section{Wilsonvi11e:}

Wilsonville is south along the Willamette River on Interstate 5 . It is a small community of near 1,200 people but is expected by some to grow to near 20,000 in the near future. It is an attractive area for industrial and residential development. Its local government and Chamber of Commerce are working hard to encourage growth. Planning for that growth is going on at the local level,but citizen participation has not been a large factor. It would appear that the threat of too rapid growth is not felt by most residents. Older residents of the area are reported to be threatened by urbanization.

The residential area is made up mostly of one large housing development and a mobile home park. The incorporated city limits cover 5.5 square miles, most of which is undeveloped.

The outstanding feature of Wilsonville is that it has the potential to become quite a large city. It has the necessary means of transportation and willingness to grow. It is also far enough away from Portland to be recognized as a separate city.

\section{Oak Grove-Jennings Lodge Area:}

Oak Grove-Jennings Lodge is an unincorporated area which lies between Milwaukie and Gladstone. It has many unique characteristics. It is just as densely populated as Milwaukie and Gladstone but is larger than either and thus has more population. There are commercial areas, but it is primarily residential. This area has its own sewage, water, and fire districts. It strongly resists being annexed.

Moves by Milwaukie and Gladstone to annex the area have failed, and so outward growth of those cities is restricted. This is reportedly a source of aggravation for these cities. The county has jurisdiction over this area and provides planning, zoning, and protection as well as other services.

The important aspect of this area is that a city exists without being incorporated, and it is uncertain how long this condition can continue. 
Summary of the Willamette River Area

This study area contains many diverse communities, yet commonalities can be observed. Citizen involvement seems to depend on two main factors: the degree of threat sensed by the people and the emergence of community leaders. While communities vary greatly in their degree of citizen involvement, each appears to have the potential for good citizen involvement. Such involvement will influence decision-making.

The most common bond between the communities was the issues with which they are concerned. Growth and all related problems such as development, sewage, water, land use, delinquency, education, taxes, and transportation were on people's minds.

The ways in which people deal with problems showed some commonalities. Most areas formed either permanent or ad hoc citizen groups to study problems and voice opinions. In all cities people used their votes to deal with problems, and finally, in all communities people used personal appeals to local officials to solve problems.

The communities seemed optimistic in that each in its own way had some positive aspects. There are no large pockets of disadvantaged people, although there are low income people in most of the communities.

As for this area's role in the metro area, it appears to be mainly residential, with a fair amount of industry and commerce. Its population is heterogeneous in terms of income and occupation but homogeneous in terms of race.

\section{Profile Data}

Following is a descriptive statistical summary of the Willamette River Communities. One should note the high percentages of youth in most of the tracts. A wide range exists in the percentage of elderly in census tracts as is also the case with percentage of blue collar workers. The very low percentage of nonwhite population varies little among the census tracts and is very apparent in the graph.

There is no indication of a very high income area. This would support the suggestion that Lake Oswego's stereotype of high income is more imagined than real. 
Total Pop. 103,625

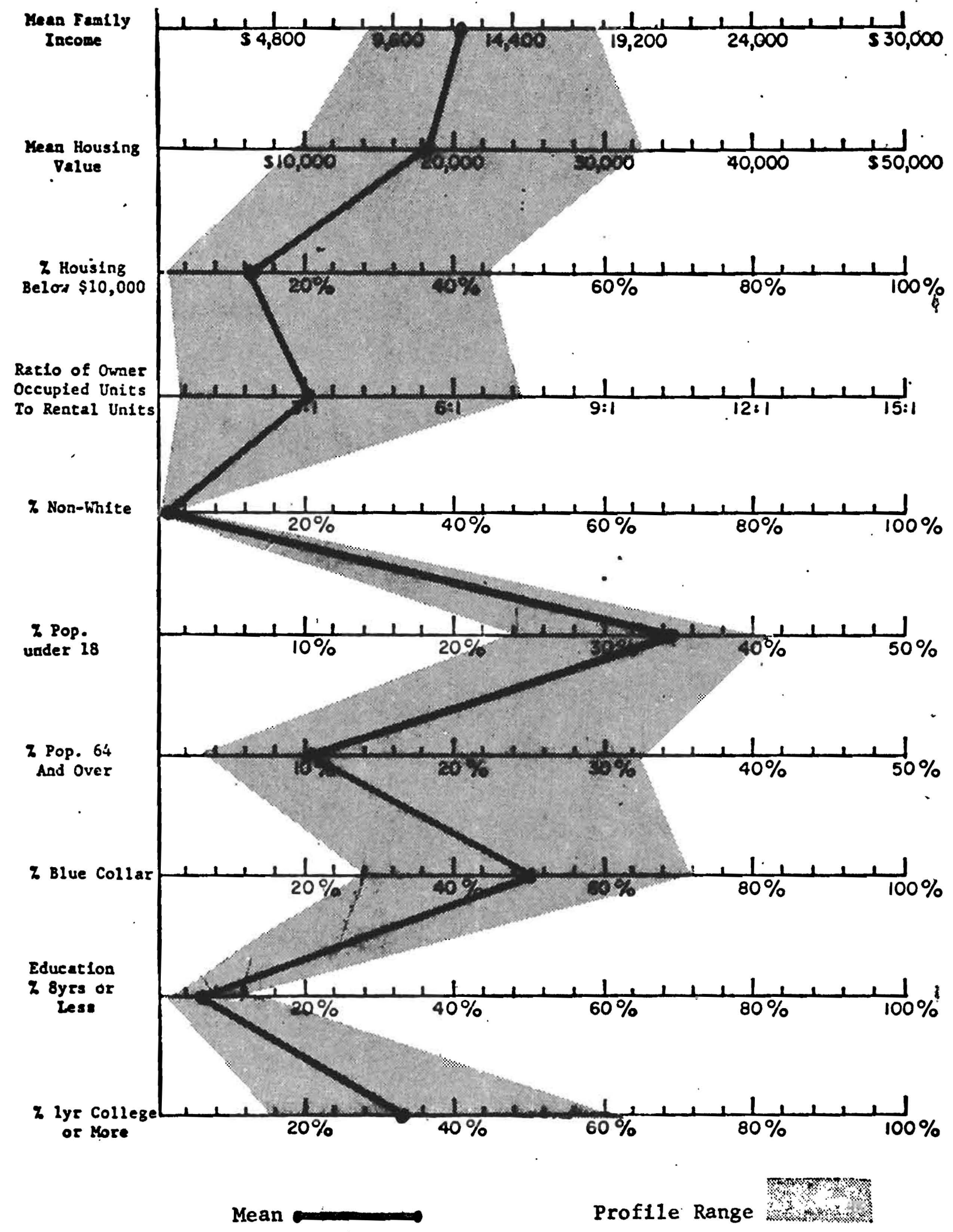


Mean Family Income . . . . . . . . $\$ 12,186$

Mean Housing Value . . . . . . . . 18,366

$\%$ Housing Below $\$ 10,000$. . . . . . . $12.39 \%$

Ratio of Owner Occupied

Units to Rental Units $\ldots . . . . . . . . . .3 .08: 1$

$\%$ Non-White . . . . . . . . . $1.03 \%$

$\%$ Population under 18 . . . . . . . 34.15\%

$\%$ Population 64 and over . . . . . . $10.21 \%$

$\%$ Blue Collar . . . . . . . . . $50 \%$

Education,

$\% 8$ yrs. or less ........... $6.81 \%$

\% $1 \mathrm{yr}$. College or More . . . . . . . 32.64\%

*A11 statistics based on 1970 census data. Statistics indicating dollar figures are substantially lower than present values due to inflation.

Education data covers males $20-49$ years old and females $15-44$ years old due to availability of data.

The Profile Range represents the range of individual mean scores of the census tracts within the profile area. 
PROFILE NO. 2

THE URBAN FRINGE

\section{Overview}

The urban fringe described here is that area which includes the incorporated and nonincorporated urban areas adjacent to the city of Portland, excluding the Willamette River communities. The incorporated cities of Beaverton, Tigard, Tualatin, King City, Durham, Fairview, Wood Village, Troutdale, and Gresham are included, plus the unincorporated area between Gresham and the city of Portland and the unincorporated adjacent urban areas west and south of the city of Portland. Many of these areas have names, such as Cedar Hills, Cedar Mills, Aloha, Oak Hills, West Slope; Raleigh Hills, Progress, and Metzger. These areas have at least one thing in common: they have been created or engulfed by Portland's urban expansion.

Because of the nature of these communities as a creation of urban growth, they have been grouped together. They are of two types, old communities engulfed by urban expansion and new communities created by it.

These fringe areas include some, but not a great deal, of industry. With one or two exceptions, each area has developed as a residential area and then tried to attract industry. The industry which has moved in is concentrated along major highways and railways, and is mainly light manufacturing, electronics, and agri-lumber related. For the convenience of the reader, the profile will look at the Greater Beaverton Area, the Greater Tigard-Tualatin Area, and the Greater Gresham Area. Following are impressions given by those interviewed concerning the Urban Fringe.

\section{The Greater Beaverton Area}

The Greater Beaverton Area is a densely-populated area west of Portland and south of Forest Park. It includes the incorporated city of Beaverton, plus the unincorporated areas of Cedar Mill, Cedar Hills, West Slope, Raleigh, Aloha, Oak Hills, and several other developments named and unnamed. When one drives west from Portland one passes through this area. The city of Portland and the Beaverton area are geographically separated by high hills and greenery, but there is a definite feeling that this is a suburban extension of Portland. At one time the city of Beaverton was a small community with its own identity, ten miles from downtown Portland; today its boundaries are difficult to determine. To the north and west new housing developments have changed what was rural into urban, and the legal boundaries do not match the area normally associated with Beaverton. 
As can be seen in the Census data, Beaverton and its surrounding developments have become a center for upper middle to upper income people. Respondents indicated that the Greater Beaverton area has some unique characteristics. Because of the nature of the occupations of many of the residents of this area, mobility is high. People are reportedly concerned with the salability of their property and support those things which will enhance its value. The school district is an example. People are attracted to the good schools and high quality homes. They in turn support a high standard of education. Further examples would be the community support of commercial development and local improvement projects. Aside from these issues, those interviewed saw little citizen involvement.

The things which people react to center around growth and money. Zoning, 1 and use, taxes, and education are all issues. Each of these touches the individual at some time. When confronted with problems, people are most apt to turn out for public meetings, as opposed to directly calling local officials or forming community organizations. It was suggested that this may be because mobility inhibits both formation of community organization and getting to know local officials.

One of the strengths of this area is that it does have enough industry to help its tax base. Over 500 acres of Beaverton is zoned industrial and much more area outside of Beaverton is also industrial. Tektronix and GAF are the largest employers. Beaverton also seems to benefit from high real estate values with a fast-moving housing market. Another strong point already mentioned is the school districts. The high quality reputation helps attract people to the area. For these reasons and because this area has one of the easiest access routes to Portland in terms of traffic, it is an attractive place to live for those who can afford it.

The urbanization of Beaverton and the surrounding area has caused some interesting conflicts. There is some division between the "old guard" residents and the newer mobile society. Several times the old guard has successfully organized to prevent a downtown mal1, zoning changes, and land use planning. At the same time, local officials come from the newer residents, are young and progressive and have made Beaverton an important supporter of regional government and land use planning.

The weaknesses of this area are evident to its residents. Because of its rapid growth, there are problems with transportation, sewer, and water. Nonincorporated areas are under county jurisdiction. This creates a problem with the provision of services in areas which are heavily developed. Also because of rapid growth, there is a lack of close recreation and parks. Interviews indicate that people leave the area to find recreation. The area also suffers from growth-related social problems such as delinquency, crime, drugs, and mental health problems.

With a mixture of old and new, incorporated and nonincorporated, the communities of Beaverțon and those surrounding have little identity. This lack of identity hinders community involvement and currently it is 
mainly specific problem-oriented groups and those citizens' committees and boards appointed by county and local officials who are "involved." The residents of the city of Beaverton have local officials to contact, but those in unincorporated areas have only more distant county government. This lack of local government is one concern of these areas.

Overal1, the Greater Beaverton area is an attractive place to live. It is a bedroom community of Portland. People shop, work, and find recreation and culture in Portland. Physically attractive, the newer developments around the city of Beaverton seem to attract a relatively high

- income group.

The Greater Tigard-Tualatin Area.

This area is located southwest of Portland, south of Beaverton, west of Lake Oswego, and north of Wilsonville. It includes the incorporated areas of Tigard, King City, Durham, Tualatin, and Rivergrove. It also includes nonincorporated areas known as Metzger, Progress, Greenbury, and Bonita.

This area is somewhat different from the Beaverton area in that many of the growth areas have been incorporated, all but one (Tualatin) since 1961. These communities are also easier to describe individually as they appear more separated from each other than do the Beaverton area communities. Tigard, Progress, and Metzger are the only areas where boundaries with the city of Portland are blurred.

The Progress-Metzger area is that nonincorporated area between Beaverton and Tigard. It is characterized by a relatively high degree of industry. This is mostly due to the presence of a main rail line and Highway 217, and to its proximity to Portland. This area is home of Washington Square, one of the largest mall-type commercial centers in the metro area. This mall attracts people from many areas around Portland.

The city of Tigard was incorporated in 1961 and has grown rapidly, doubling in population from 1970 to 1974 . 5/ Tigard is located approximately eight miles southwest of Portland on Oregon Highway $99 \mathrm{~W}$. It was reported to suffer from the same lack of identity as the Beaverton area. It was also reported that citizen participation here is minimal. People serve when appointed to committees and have reacted when issues arise, but little pro-action citizen involvement takes place. The Washington County Citizen Planning organization has organized the people of Tigard and is having a positive influence.

Tigard has a public school system and one parochial grade school. The Sylvania Branch of Portland Community College is located nearby. Tigard has one of the better recreation facilities with four parks and a yearround swim center. The community also has its own newspaper, the Tigard Times.

5/ Oregon Blue Book, p. 210 . 
King City was incorporated in 1966 and has a population of about 1,980. It is a planned residential development for older people, and it incorporated to have a degree of autonomy. The area has grown but not extremely rapidly. It is nearly all developed. The issues are centered around taxes, and its residents have effectively used organization and the ballot box to be heard.

Durham is also a recently incorporated area; its population has actually dropped since its incorporation in 1966. With a population of 330 people, Durham exists incorporated because its people wanted to protect themselves from annexation by Tualatin.

Rivergrove, incorporated in 1971, had about 320 people in 1974. It appears to have incorporated for much the same reasons as Durham. It has little room for growth and has little citizen participation.

Tualatin is located south of Tigard on I-5. It gives the feeling of being separated from Portland by a less densely-populated area and the Tualatin River. Its population is about 2,800, and it is the oldest city in this fringe area, incorporated in 1913. It has recently undergone rapid growth, growing from 750 in 1970 to 2,800 in 1974.6/ This area is unusual in that there is more industry here than the population can serve, and people from Beaverton, Tigard, and outlying areas are attracted to jobs in Tualatin. It appears to be the only fringe area in which industrial development has preceded residential.

Tualatin faces many of the same problems as Tigard and Beaverton with rapid growth but has the strength of established industry and a stronger community identity.

\section{The Greater Gresham Area}

The Greater Gresham Area is that fringe area east of Portland and Milwaukie which includes the nonincorporated area between Portland and Gresham, and the incorporated areas of Gresham, Happy Valley, Fairview, Wood Village, and Troutdale. It is a difficult area to summarize because of the vast urban area between Gresham and Portland. This nonincorporated area appears to be two part: residential and commercial. Along the main highways, primarily east and west, commercial development lines the roadside. There is no town center area, and thus one needs a car to get around. There is no widely known or used name for this area. Those interviewed indicated that people have almost no community identity.

The county is their closest level of government. - With the exception of fire, water, and school districts, the people depend on county services.

\section{6/ Ibid.}


This area is an important one and further study is necessary.

The city of Gresham, like Beaverton, was an old town caught up in urban growth. Incorporated in 1905, it has grown from 365 people in 1905 to 5,400 people in 1965 to 21,500 in $1975.7 /$ This rapid growth has created many of the same problems of other rapid growth areas. Land use planning, taxes, schools, and traffic are seen as the most important issues. To deal with these problems people usaally turn out to public meetings. Interviews indicate that there is little use of the community organization, and citizen involvement is low to average. Most of the citizen participation has come in the reaction to land use. Because the city has grown in area from $8.5 \mathrm{sq}$. mi. to $16 \mathrm{sq}$. mi., there have been many emotionfilled zoning issues. Land use planning is seen by most as a threat to individual freedom and thus the people dislike and distrust any agency associated with land use planning. For this reason Gresham has reportedly been the strongest adversary of CRAG in the fringe area.

A special problem for Gresham is the fact that it is on the road to the recreation areas at Mt. Hood. This causes a traffic problem. A further concern for Gresham is the lack of industrial development. More and more it is becoming a bedroom community. As the urban area between Portland and Gresham has become more dense, the distinction between them as separate entities has become less.

Gresham gains strength from having a town center, a progressive school system, very adequate recreation facilities, and full city services. It has a community college with an enrollment of about 12,000 , and it has a weekly newspaper, The Gresham Outlook. There are 21 churches, representing 17 denominations, in the area. Overall Gresham is an attractive place to live. Growth is a problem but as yet no organized community involvement has arisen to meet the problem. The city government has been very active in planning for future growth.

Troutdale, Wood Village, and Fairview are three adjacent communities north of Gresham. Together they have a population of about 6,000 . They, too, are experiencing rapid growth and associated problems. Their citizen participation is comparable to Gresham's and, except for Gresham's Mt. Hood traffic, their problems are very similar. Troutdale is experiencing more problems in the area of sewage.

An advantage these areas have is a feeling of separation from Portland, small town atmospheres, and local services and officials. There is an airport at Troutdale which is controlled by the Port of Portland. Troutdale is expected to be an area of very rapid growth, as it is an attractive place to live, and there is apparently much room for development.

I/ Ibid. 
Finally, Happy Valley is south of Gresham and east of Milwaukie. It is geographically separated from surrounding communities and has a small town atmosphere. It was incorporated in 1965 and has a population of about 1,500. Because of its separation and low density, there is a feeling of being rural. The people want to retain that feeling. Citizen involvement is very high and is considered to be action-oriented.as well as reactive. At one Department of Environmental Quality meeting, 600 people turned out. The population seems to be mixed older people and upper income. The area has the knowledge, expertise, and human resources to be a potent force in citizen participation.

$\underline{\text { Summary }}$

To summarize the Urban Fringe, it seems that the outstanding issue is growth. People are concerned about too-rapid growth, but at the same time want to maintain individual freedoms. Citizen participation in government, planning, and community affairs is, with one exception, not very high. It appears that a wide range of income levels exists in the fringe but that there are no real areas of poor people.

One underlying theme seemed to be the problem of urbanized unincorporated area. There appear to be problems for both county government and the people.

One area of further investigation might be to determine on what variablés citizen participation depends.

\section{Profile Data}

The following descriptive data covers the Urban Fringe area. Like the Valley Communities, the graph indicates a very low percentage of nonwhite population. The range of income reaches higher than the valley Communities, but the mean remains about the same. The percent of population under 18 ranges above 42 percent. This, along with the low percentage of elderly, indicates that these are areas of concentrated youth. The graph also shows a narrow range in the age characteristics indicating a degree of homogeneity. 
Profile Data - Urban Fringe*

Total Pop. 232,512

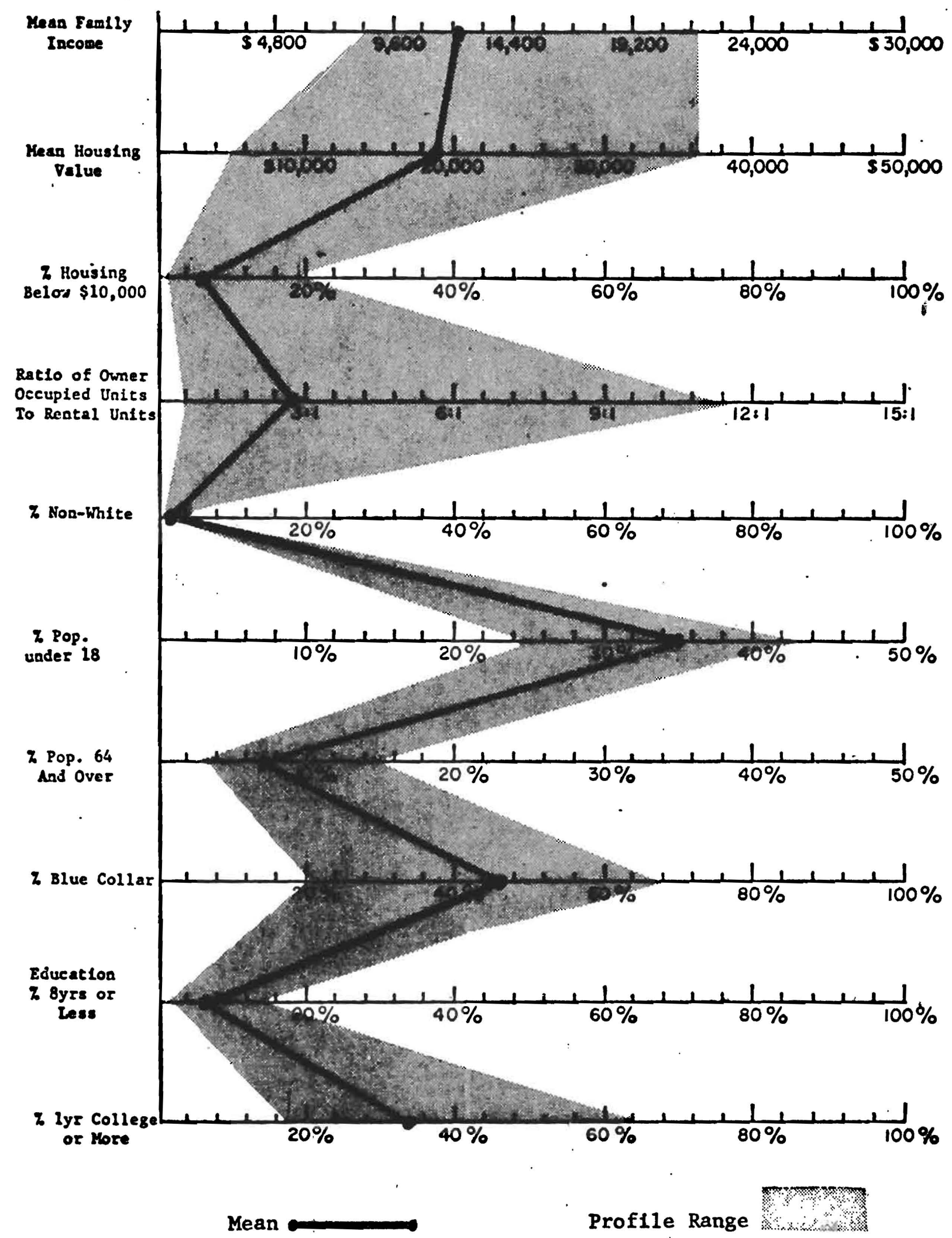


Mean Family Income . . . . . . . . $\$ 12,257$

Mean Housing Value . . . . . . . . 18,872

$\%$ Housing Below $\$ 10,000$. . . . . . $5.92 \%$

Ratio of Owner Occupied

Units to Rental Units ........ 2.86:1

$\%$ Non-white........ $.21 .57 \%$

\% Population under 18 . . . . . . . 35.26\%

\% Population 64 and over . . . . . . $7.41 \%$

$\%$ Blue Collar ................. $46 \%$

Education,

$\% 8$ yrs. or less . . . . . . . . . $5.89 \%$

$\% 1 \mathrm{yr}$. College or More ........ . 34.29\%

* Al1 statistics based on 1970 census data. Statistics indicating dollar figures are substantially lower than present values due to inflation.

Education data covers males 20 - 49 years old and females $15-44$ years old due to availability of data.

The Profile Range represents the range of individual mean scores of the census tracts within the profile area. 
PROFILE NO. 3

THE OUTLYING CITIES AND TOWNS

The outlying towns have been defined as incorporated cities outside of the urban fringe area and with population over 1,000. There are about 13 such communities in the Metro area, four from Washington County, four from Clackamas County, two from Columbia County, and three in Clark County, Washington. Unlike much of the fringe area, each of the outlying communities is old and has characteristics which set it apart from other communities and the larger Metro area. Their history and their individual identities give them a unique relationship with the Metro area.

Industry is centered around agriculture and lumber, with some light manufacturing. Availability of transportation has been a factor in growth as has distance from Portland. Most of these communities serve as centers for public schools. The communities have varying degrees of access to health, social services and churches. Following are some impressions about the cities taken from interviews.

Washington County Communities - Hillsboro, Cornelius, Forest Grove, and Sherwood.

\section{Hi11sboro}

Hillsboro is located 16 miles west of Portland in the Tualatin Valley and is the county seat of Washington County. Incorporated in 1876, it now has a population of about 18,800 . The major industries are wood and wood products, food processing, and light manufacturing. Hillsboro is served by rail and highway, plus the Hillsboro general aviation airport. There is a public school system plus two parochial grade schools. There are about 30 churches of nearly all denominations, five city parks, and a new library. The city has full city services plus the 90-bed Tualatin Community Hospital. The local paper, The Hillsboro Argus, is published twice a week.

Hillsboro is the largest of the outlying cities. Its position as the county seat gives it a strong identity. It is the main distribution point in Washington County for county services. It also serves as a central shopping area for the surrounding rural areas. It has a strong small town atmosphere, and local planning efforts show a desire to retain that.

Interviews indicate that the people of Hillsboro are very independent and have a pride in existing as somthing very separate from Portland. The community is concerned about its rapid growth but at the same time is very interested in individual rights and freedom. For this reason, citizen participation seems to be strong in the area of reaction to land use planning. Neighborhood groups are starting and appear to have the potential to be pro-action as well as reactionary. A further problem which has spurred 
citizen involvement is a general dissatisfaction with county government. Many people perceive the county government as becoming distant from them. Where a call to a local official might have had some impact in the past, many people now feel they must come together as a group to make themselves heard. People are concerned about the drastic changes that growth brings, about county administration, and about individual and community individualism.

Hillsboro would like to attract more industry and feels it has the necessary facilities to accommodate it. The community seldom fails to support cultural and educational things such as its library.

An important issue in Hillsboro is its relationship to the rest of the Metro area. While it enjoys having the resources of Portland close by, it resents strongly having to be a part of service districts such as Tri-Met. Most people feel they are being taxed for a Portland city service. They also somewhat resent having to comply with LCDC and CRAG directives. Such ire increases the degree of citizen involvement. The strong desire to remain independent of the metro area does not always fit as many Hillsboro residents commute to Portland and the fringe area.

\section{Cornelius}

Cornelius is located about three miles west of the legal boundaries of Hillsboro and three. miles east of the legal boundaries of Forest Grove. However, the growth of both towns has approached the borders of Cornelius. It was incorporated in 1893 but has remained a slow growth area. Its population of about 2,500 lives on either side. of Route 8 . There is some industry, a commercial area, two elementary schools, and one junior high school. There are also six churches, two city parks, and a public library.

A health clinic for low income families operates in Cornelius and serves mainly the Spanish-speaking migrant farm labor families. Cornelius and Hillsboro seem to be the center of the Spanish-speaking population of the Metro area. The Washington County Community Action Agency publishes a rural paper in both Spanish and English.

There is a citizens's planning commission in Cornelius, but local officials tend to regard participation in CRAG and planning as impositions. There does not seem to be a strong community identity, perhaps because it is sma11 and so close to other communities. The same sentiments against outside control and intervention are evident in Cornelius as in Hillsboro.

\section{Forest Grove}

Forest Grove is located west of Cornelius. As mentioned, leaving Cornelius west will immediately put, you in Forest Grove. It is an old city, one of the oldest in the area. Its population of about 10,000 centers around lumbering and some light industry. The greatest factor affecting the city is Pacific University. The small town atmosphere and the old university give Forest Grove a New England quality. A downtown commercial area which appears quiet but efficient coupled with the intellectual and cultural influence of the university tends to make one forget that Portland is only about 35 miles away. 
Because of the distance to Portland and because of the apparent balance between population and employment, few of its residents commute past Hillsboro. Forest Grove is inclined to give more than average attention to social services and community organization. There is a higher degree of pro-action planning here than in other outlying communities, and its planning has included positive attempts to maintain the pleasant community.

Sherwood

Sherwood is a sma11 community of about 1,765 residents. It is 16 miles southwest of Portland on Route 99W. Sherwood has four small light manufacturing plants and is served by rail and truck transportation. Because of the easy access to Portland, the area could soon grow into a bedroom community.

At this time, however, it remains a slow growth area. It was incorporated in 1893 and has an old rural town quality as do many of the outlying towns. Most growth problems experienced in other areas have not yet been serious, although the prospect of becoming a bedroom community is a hot issue. Sherwood shares the sentiments of Hillsboro and Cornelius with regard to regional districts and governments, but the community does enjoy the opportunities for culture and recreation in Portland.

Sherwood has two newspapers, Tri-City Times, a weekly, and The Sherwood Scro11, a month1y. These papers, plus Sherwood's separation from other incorporated areas, add to its identity.

Clackamas County Outlying C1ties - Estacada, Sandy, Molalla and Canby.

If Washington County outlying communities could be generally characterized as remnants of farming communities, then Clackamas County towns would have to be characterized as being remnants of cowboy, lumber jack towns. More spread out and smaller, the feeling of being a place for surrounding rural folk to get together is much stronger here.

\section{Estacada}

Estacada lies about 28 miles southeast of Portland in the foothills of the Cascade Range. It has a population of about 1,550, most of whom are employed in lumber and wood products industries. Estacada is served by only highway transportation. This is probably one reason for its slow growth since 1905 when it was incorporated. As with other outlying towns of this size, Estacada provides the place for a central high school and elementary schools. There are a small commercial center, 16 Churches, and a public library. It is surrounded by recreation areas but depends on Portland for cultural events and higher education.

Estacada is felt to have few ties to the Metro area. It is a mill town and there is little growth pressure. There is little citizen involvement in planning as there is a very strong anti-regulation, anti-regional government sentiment among the people. Estacada has the potential, because of its frontier spirit, to be a strong reactionary force against land use planning. 
$\underline{\text { Sandy }}$

Sandy, Oregon lies 25 miles southeast of Portland along the Mt. Hood Highway. Incorporated in 1913 , its population is about 1,900 . It also has been a slow-growth area and is dependent on lumber and related industries. Sandy is served by the Tri-Met bus system, but it does not appear to be a bedroom community as most of the residents are employed there. It has less of the smal1-town atmosphere than most outlying communities. Like Estacada, it is the location of a public grade school and high school. There are 13 churches in Sandy, 3 parks, and a public library. The closest general hospital is eleven miles at Gresham. It reportedly shares the anti-regulation sentiment of Estacada, but it would appear that Portlanders attracted by Sandy's accessibility to Mt. Hood may be influencing a change in community sentiment.

\section{Mola11a}

Molalla is a community of about 2,625. It lies 27 miles south of Portland and seems to be the community most isolated from the city of Portland. Its economy is almost entirely based on the lumber industry. It supports not only its residents but also a great number of people from the surrounding rural areas. There is a strong rural, small town community identity. The area is served by rail and highway transportation. It serves as the base for a public school, has 10 churches, a city park, two county parks, and a public library. The Pioneer is a weekly newspaper which reflects the sentiment of the people.

Molalla is a stronghold for ultra-conservative groups, such as the Patrick Henry Society and the Posse Comatatis. There is also a powerful reactionary group known as the Rural Landowners Association. The sentiments expressed by these groups have influenced county land use plans. Molalla has an even stronger anti-regional, anti-regulation sentiment than Estacada. It has been said that Estacada's sentiments are the same; they are just more polite about them.

Canby

Canby has experienced rapid growth and has many of the growth problems familiar to Hillsboro. It is a community of 5,440 located south of Portland along Highway $99 \mathrm{E}$, and is the largest outlying town in Clackamas County. It, too, is an old town, incorporated in 1893. Canby is served by rail and highway transportation and its major source of employment is the lumber and wood products industry. It too, is the location for schools and provides churches for nearly every denomination. It has a commercial center, but the traffic of $99 \mathrm{E}$ takes away from its small town feeling. It would be safe to assume that many of Canby's residents commute, if not to Portland then to Oregon City and Milwaukie.

Recently it has experienced internal problems in addition to the problems of growth. Faced by anti-land use planning sentiment and a rapid growth factor, the city is in a difficult position. At this point, local 
politics prohibits solving, or even examining, issues in the community. The local problems have brought out a great deal of local citizen involvement.

Columbia County Outlying Cities - Scappoose and St. Helens

\section{Scappoose}

Scappoose is a community of about 2,545 residents located adjacent to the Columbia River, approximately 20 miles northwest of Portland. Industries in Scappoose include electronics, shoe manufacturing, food processing, and lumber-related industries. The area is served by rail, highway, and water transportation. There is a public school system including a high school. there is also a private grade school. There are many recreation facilities, churches of every major denomination, and a city library. The local paper, The Columbia Herald, is published week $1 y$.

Residents of Scappoose work in Scappoose, St. Helens, and Portland. Because it is within commuting distance of Portland, Scappoose identifies more with the Portland Metro area than does the remainder of Columbia County. A small town, it seems to also have an identity of its own. It is a voluntary member of CRAG and has been supportive of that agency. The progressive cooperation found in Scappoose is unusual for a community of its size, so near to a major urban center.

St. Helens

St. Helens is a deep-water seaport about 30 miles northwest of Portland on the Columbia River. It is the county seat of Columbia County and has a population of about 6,855 . Its economy depends on lumber and wood-related industries, and the area is served by rail, highway, and water transportation. St. Helens is the site of the district high school and has numerous grade schools. There are churches of all major denominations, recreation facilities, and a public library. St. Helens is also the site of a modern 84-bed hospital. The area has two newspapers, The Longview Daily News and The Sentinel-Mist Chronicle, the latter published twice a week. St. Helens also has a local radio station, KOHI.

Being the county seat, St. Helens reflects much of the county's feelings. This has not been an area of rapid growth, and the problems that accompany growth are not pressing. The same strong anti-regulation, anti-regionalism exists in St. Helens as in Estacada and this area, like Molalla, has strong conservative groups such as the Posse Comatatis. Strong anti-land use planning sentiment led to Columbia County's withdrawal from CRAG. The people use their voice with local groups, local officials, and newspapers to show their sentiment. The community involvement is above average and an effective reactionary force.

Clark County Outlying Cities - Camas, Washouga1, and Battleground 
Camas, Washington is a small community about 15 miles east of Vancouver. Interviews would indicate that it is almost entirely dependent on the Crown Zellerbach paper and pulp mill located there. It is one of the few towns in the area that has such a dependence on one manufacturer. The mill also draws people from Vancouver and other areas. Despite the employment opportunity, Camas is not a rapid growth area. There are two reasons for this. The air pollution problem discourages new residents, and also there is little attraction for living there other than the industry. The area has many strong points. The industry provides a tax base which provides good schools and streets. The community/has a solid identity, sma11 town atmosphere, and because of its situation geographically and economically, it is not a bedroom community. Growth and the problems which result have nat been a real problem. The completion of the new I-205 bridge may, and probably will, change that.

\section{Washouga1}

Washougal is an older community than Cémas and has its own industry. However, many people who live in Washougal work at the mill in Camas. The Washougal industries include woolen mills and light industry.

Washougal began as a service area to the surrounding rural area, and has two problems which have kept growth down. First, it suffers from the same air pollution as Camas, and second, without Camas' rich industrial tax base, the quality of community services is not as high. Like most of the other outlying towns, except for Hillsboro and Forest Grove, Camas, and Washougal are blue collar towns with few rich or poor areas.

Washougal has its own city center and identity as a small town. It could not be considered a suburb.

\section{Battleground}

Located about 15 miles north of Vancouver, Battleground is a-rapidly growing, and rapidly changing community. Until recently, it was a very small commercial area which served the surrounding rural area. Now it is becoming an area for development. Commuters to Vancouver and Portland are beginning to settle there. It has little industry and has the potential of becoming a large bedroom community. It also is the site of the district high school, the biggest district in the county.

The old guard residents are mixed in their feelings about the new growth, this appears to be an area where land use planning will soon become an issue. It would appear that groups will begin to form with the aid of the County Extension Service and Regional Planning Council. The quiet small town atmosphere, the distance from Vancouver, and the beautiful scenery around Battleground make it seem untouchable as an area to develop, but it has already begun. 
In conclusion, it is apparent in all of the outlying towns that the sentiment of independence is strong and the reaction to threats to that independence is potent. Citizen involvement seems determinant on reaction to perceived threats. In these primarily blue collar towns, pro-active planning seems less of a priority. The interviews suggest two reasons, one the antigovernment and anti-land use planning sentiment, and second, the need for concern with personal survival.

Each of these areas seems to have some industry, and each has at least a few Portland commuters. Recreation and community services seem to be avallable and accessible. The populations, with the exception of Hillsboro, seem to be quite homogeneous in terms of race and occupation.

\section{Profile Data}

The following statistical presentation describes the Rural and Outlying Towns profile areas. It was necessary to combine these two areas due to the character of the available census tract data. The graph indicates the high percentage of youth and blue collar employment in all tracts. The low percentage of population with more than a year of college is similar to North Portland. Of special note is the narrow range in each of the characteristics. 
Total Pop. 200,186

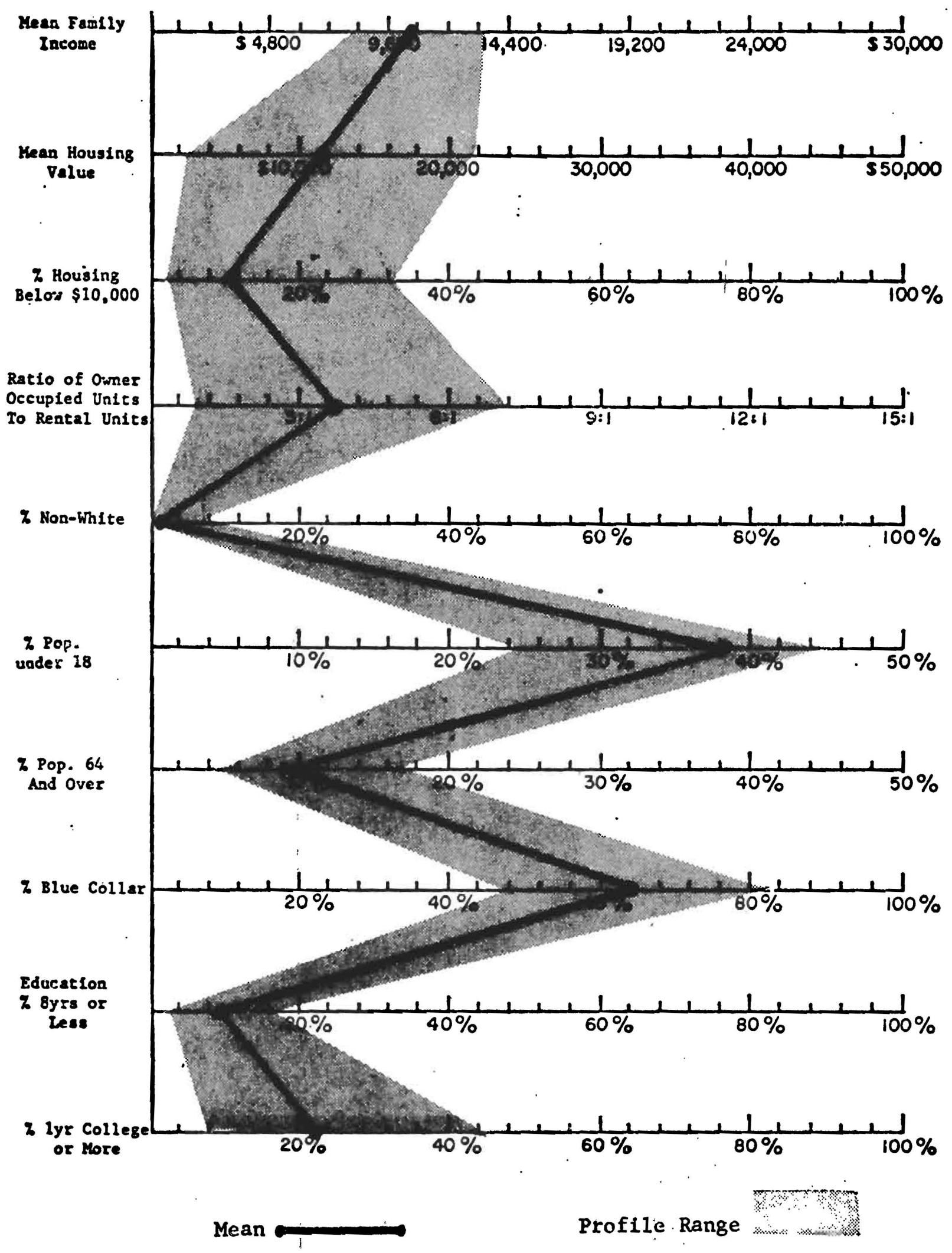


ACTUAL MEAN SCORES

Mean Family Income . . . . . . . . . \$ $\$ 10,626$

Mean Housing Value ............. 11,717

$\%$ Housing Below $\$ 10,000$. . . . . . . $11.00 \%$

Ratio of Owner Occupied

Units to Rental Units.......... . 3.74:1

$\%$ Non-White . . . . . . . . . . $1.25 \%$

$\%$ Population under 18 . . . . . . . . 38.06\%

$\%$ Population 64 and over . . . . . . . $8.76 \%$

\% Blue Collar . . . . . . . . . . $64.30 \%$

Education,

$\% 8$ yrs or less............... . . . $9.42 \%$

$\% 1$ yr College or More . . . . . . . $22.89 \%$

* All statistics based on 1970 census data. Statistics indicating dollar figures are substantially lower than present values due to inflation.

Education data covers males 20 - 49 years old and females 15 - 44 years old due to availability of data.

The Profile Range represents the range of individual mean scores of the census tracts within the profile area.

Statistics for Rural areas and the Outlying towns are combined due to the inability to separate census information for these two areas. 
PROFILE NO. 4

THE RURAL AREAS

The history of the rural areas in the Metro area is long and meaningful. The rich fertile valleys and the great stands of timber were the attraction that brought people to this area. Even before statehood there were farmers' organizations in Oregon. The Grange in Oregon became one of the most powerful farm organizations in the United States, and Oregon remains one of the last strongholds. With the growth of lumber and agriculturerelated industries, a metropolitan area began to grow. With the advantage of a deep water port, the area had good access to shipping. This was an early incentive to agricultural growth.

Urbanization is relatively new when looking at the history of the area. Much of the area has turned from rural to urban since World War II. This growth is a basis for many rural issues today. The outlying areas have long . depended on small towns and cities for subsistence needs. Most of the outlying cities sprang up to serve these needs. Small communities grew along rail lines, main highways, and in valleys for the same reason. People in rural areas depend even more now on the cities and towns for shopping and employment, but there remains a special rural quality of independence from Portland. One gets the feeling that Portland is a resource, to be entered only when one wants or has to. This is particularly true of the rural-born. Today there is a great growth of people who want to live in rural areas and work in the city. These people are striving for what they feel is the best of two worlds.

This profile will deal with the rural area in each county of the study individually as each has some unique characteristics. As with the other profiles these are impressions of the areas, supplemented with available statistics.

\section{Washington County}

In 1969 the U. S. Census of Agriculture showed 953 commercial farms in Washington County averaging 144.3 acres per farm. Since then it is probable that the number of farms has decreased due to rapid development in many areas, especially the Tualatin Valley. The value of farm products sold in 1973 in Washington County was $\$ 41.9$ million. The principal products produced were specialty horticultural/crops, berries, fruits and nuts, grain, dairy products, and poultry. The majority of the farming operations in Washington County are west of Beaverton in the Tualatin Valley. The foothills of the Coast Range contain a mix of agriculture and logging.

8/ Portland General Electric, A Community Profile of Hillsbore. Portland, Oregon. 1974. 
The incorporated rural towns in Washington County are Banks, North Plains, and Gaston. These communities are small and old but have a surprising variety of commercial and financial establishments. They exist mainly as service areas for the surrounding rural areas. Many more smaller and unincorporated communities exist in the county. They serve as local places for the exchange of information and conversation.

Citizen participation is seen at the rural level to be high in proportion to the number of people. The quality of that participation is also seen as high. The rural areas are often associated with being backward, slow, and unsophisticated. This is a great underestimation of the ability there. Rural folk are often assoclated with being super conservative. This also may be a false assumption. Three basic reasons for the quality of rural citizen participation we re aseertained from interviews. First is the farming history. The farmers were the fathers of Oregon's style of citizen participation. The many farmers' organizations which exist today involve a large segment of the rural population and thus many people are experienced in working with groups. The second factor affecting community involvement is the frontiersman quality of life. The need and willingness to meet problems and to fight for survival and rights was a quality ingrained in the settlers of the area which is still evident today. The third factor seems to be the influx of urban people, who have qualifications which give the citizens' groups a quality of sophistication. Not all of the citizen involvement in this rural area has all of these qualities, but the potential is there, and there are action-oriented groups as we11 as strong reactionary groups.

Some of the issues brought out in interviewing in rural Washington County are land use planning, trending, (raising of tax valuation due to proximity of development) corporate farming, and clear cutting. The issue of land use planning and trending is so complex that it cannot be discussed in this report. Corporate farming is an issue because many farmers fear that larger factory-type farming businesses will put the family farmer out of business. There are groups working on this problem. Clear-cutting is an issue around logging mostly in the national forest area of far west Washington County.

Other problems in the rural community include transportation, the percentage of rural poor, and housing, health, and education of the migrant farm worker. Because of the seasonal nature of the berries, nuts, and fruit harvests, there is a great influx of low-income migrant workers.

Washington County Community Action Organization is a Federally-funded operation which deals with these and other rural problems. Last year this . agency organized a gleaning project which provided over $\$ 57,000$ worth of food to low-income, elderly, and disabled persons almost entirely through volunteer efforts.

The role of rural Washington County in the Metro area is to provide many jobs in agriculture and lumber-related industries in the urban areas. It also serves as a recreation area for the urban areas, providing areas for hunting and fishing, and just getting away from the city. 


\section{Clackamas County}

Clackamas County is the largest county in the Metropolitan area and has the largest portion of rural land. Approximately one-half of that rural area is national forest. Lumbering is by far the most important economic activity producing more than 540 million board feet of lumber each year. The Agricultural Census of 1969 showed that there were 1,196 commercial farms averaging 117.9 acres per farm. In 1974 Farm production equalled $\$ 59.7$ million. Principal crops include specialty horticulture crops, fruits and nuts, livestock and poultry, legumg grass and other seed crops, vegetables, dairy products, and grain. $\underline{-}$

There are several small towns such as Mulino, Barlow, and Boring which serve the same purpose as those in Washington County. Except for the northwestern corner of the county, the rural areas have not been much affected by the influx of urban people into the rural areas. This is partly because access routes to Portland are not as well developed as in Washington County. This also serves to isolate the rural area somewhat.

The degree of citizen participation is high as it is in Washington County, but the quality is somewhat different. The frontiersman theme is reported to be much stronger here. This is probably because the more organizationally sophisticated dirt farmer takes a backseat to the lumberjack and the cowboy. This, coupled with less.influence from urban-type people, give the citizen involvement a more robust and somewhat reactionary quality. There appears to be more of a desire to get together to stop something than to start something. Citizen involvement is a potent focus in rural clackamas County.

The problems faced in this rural area are much the same as in Washington County. There seem to be more rural poor in Clackamas County, and more remote areas. Clear cutting is a much greater issue. Whether or not loggers can use the clear cutting methods of harvesting means a great deal to the economy of the area. Individuals are concerned because it affects their livelihood. Land use planning is also a very hot issue with these independent-minded people.

This area has a strong rural identity. It has an abundance of recreation, mostly, in natural resource areas, and it has a strong agricultural and timber base for its economy. It serves much the same role in the Metro area as Washington County, providing natural resources and raw goods for urban refinement and recreation.

\section{Multnomah County}

Multnomah County has the least area of any county in the state and the largest urban population. As late as the 1940's Multnomah County was rural except for Gresham, east of the city limits of Portland. Today the only real rural area left is east of Gresham, and more than half of that

9/ Portland General Electric, A Community Profile of Estacada, Portland, Oregon. 1975. 
is National Forest. Lumbering is a principal industry in this eastern portion of the county. In 1969 there were only 344 commercial farms averaging 90 acres per farm. The 1973 total value of farm production was $\$ 18.4$ million. The main crops were spectafty horticultural products, vegetables, berries, and dairy products.

There are a few small towns in the area, but they serve the tourist and recreation seekers as well as local residents. Citizen participation does not seem as great as in Clackamas and Washington possibly because the western portion of the county so overshadows the east. One seldom hears about east Multnomah County from urban residents unless it is in connection with recreation. This area is growing rapidly, and it appears that the rural areas may soon be nonexistent. Trending and land use are the two greatest issues here, but the reactionary force does not appear to be strong enough to effectively deal with problems.

Columbia County

Columbia County lies to the north and west of Portland. It is nearly all rural except for the communities and marinas along the shoreline of the Columbia River. Agriculture is important, though the area is the least suited for farming of any of the counties. As of 1969 there were 236 commercial farms, averaging 227.5 acres per farm. Products include livestock, dairy, poultry, fruit and nuts, and farm forest products. The value of farm products sold in 1972 was $\$ 7.1$ million.

Like Clackamas County, lumbering is the most important factor in the rural areas, and the quality of citizen participation and people's concerns is much the same in both counties. Columbia County is also rather remote from Portland because of the lack of well-developed highway. The area tends to get passed up by Portland as a recreation area as the Coast and Mt. Hood seem to be more glamorous.

This area seems to be relatively independent of the Metro area because it has its own economic base and its own seaport. Its role in the Metro area is uncertain.

\section{Clark County, Washington :}

Clark County, being one of the smaller counties of Washington, does not have a great deal of rural area. It is an area of declining lumbering and agricultural importance. Statistics concerning the economic base, of rural clark County are not readily available. Although there seem to be some areas left for agricultural use, much is left unused. This is a great contrast to Oregon rural areas. It has been suggested that this may be because of a lack of irrigation.

10/ Portland General Electric, A Community Profile of Gresham, Portland, Oregon. 1974.

11/ Portland General Electric, A Community Profile of St. Helens, Portland, Oregon. 1974 
The quality and quantity of citizen participation do not seem as high and the intensity of issues does not seem as strong as in Oregon. Seen as a pleasant place to live, this rural area seems destined to grow. Clark County is dotted by small towns which serve as commercial areas for the rural population and as bedroom communities for Vancouver, Camas, and Washouga1. Because of the potential growth and past growth, the issue of land use is an important one. In this rural area development is a dirty word, and while the sentiments do not now appear as strong as in some areas of the Metro area, there are the beginnings of action.

\section{Summary}

The rural areas are summarized quite well by the profiles of Washington and Clackamas Counties. Common problems and common ways of dealing with those problems seem to be the themes of the areas. With a slower pace warm, earthy, and independent - the rural areas are attracting a generation of young people with a desire for that kind of life. This, coupled with history and tradition, make these strong areas. 
PROFILE NO. 5

VANCOUVER AND ITS URBAN FRINGE

\section{Overview}

The city of Vancouver was incorporated in 1857 , and over the years its growth has been in stages with periods of rapid growth and development, and periods of slower progress. Early fur trade and lumbering gave the town a start. Since then Fort Vancouver and war industries brought growth to the area. Today it is the urban expansion of the PortlandVancouver Metro area which is bringing the rapid growth. The population of the City of Vancouver is 46,500. Clark County total has a population of 140,300. The city covers 15.65 square miles. There are two hospitals with a total of 472 -bed capacity, plus the Veterans Administration Hospital.

Geographically, it is situated north of the city of Portland, separated by the Columbia River. It is an important seaport - In 1974 there were moff than $1-1 / 3$ million tons of material shipped from the Port of Vancouver. It has a diversified industrial base, including lumber-related industries, cement, airplane repair, clothing, food processing, aluminum, and several other light industries. Besides industry, there are a great many jobs in nonmanufacturing settings.

Only one bridge connects Portland and Vancouver, but there are other ties which make Vancouver part of the Metro area. The city of Vancouver has many qualities that are quite different from the surrounding fringe areas. For this reason the profile will examine these areas separately. The strengths and weaknesses of the incorporated city of Vancouver are interesting and give some indication about its people. Impressions of those interviewed follow.

\section{Vancouver}

With regard to the people of the city of Vancouver, involvement in the community comes in many forms. There is both reactionary involvement and action-oriented involvement. As in the rest of the Metro area, actionoriented citizen involvement tends to come out of the official appointed committees and established organizations such as the Chamber of Commerce or League of Women Voters. Vancouver has a number of organizations which seem to have a hand in pro-action activities, giving the city a greater amount of positive citizen involvement than it would at first appear. Most of the reactionary type of citizen involvment comes in the form of turnout to public meetings and petition drives. Many people, usually of middle to upper income, will call their local officials directly. Much

$12 /$ Merchants Exchange of Portland, Foreign Export Statistics, Portland; Oregon. 1974. 
use is made of the local newspaper, The Columbian, in letters to the editor. These are traditionally the ways people have to express their participation. Today both the city officials and citizenry are beginning to consider the community organization as a means of citizen participation. As one local group member put it, public hearings are often like church. "The official acts like a preacher and expects the congregation to say 'Amen!' But the people don't always want to say 'Amen,"' It is felt that there needs to be a community organization to make the people's opinions heard.

One of the reasons offered for Vancouver's feeling of better-than-average citizen participation seems to be its distinct community identity. It has very much a feeling of being a small, older city. Its established organizations take pride in the community and work for its betterment. Other citizens are concerned that their needs are being served by the city. Partly because of the pro-action groups, there are positive things happening there. The dredging of Vancouver Lake, the restoration of Fort Vancouver, senior citizens' programs, community gardens, and a high standard school system are among the strengths of the city. Most respondents felt that their local officials are accessible. The city also has a strong financial base, with many financial institutions, diverse industry, and the port. There is recreation in and around the city and all of the benefits of Portland just across the river. There are no visible racial problems, partly because minorities represent only about 1 percent of the population and are not centered in any given area.

Vancouver does have some weaknesses. Most mentioned is a public transportation system. Unless one lives downtown, it is almost a necessity to have a car. Another part of the transportation problem is the lack of adequate access to Portland. The single bridge causes traffic jams every day. The city lacks a four-year college. The Clark Community College, with 8,590 students, serves the area as a two-year school. Across the state line in Oregon, four-year schools are available but the tuition is higher for non-residents. One serious lack that adversely affects the community's independent identity is the lack of a television station. A11 Portland stations are received, but local Vancouver news and Washington State news does not receive much attention.

Weighing strengths and weaknesses, there seems to be a theme of optimism running through Vancouver. A fear that things might get worse has sparked citizen involvement and active city planning. Business is reportedly encouraged by the growth as shown by its willingness to invest in the area. Most of all, the optimism centers around a desire to hold on to the good things the city has while being able to grow and get better.

The role of Vancouver in the metropolitan area is marked by its independence. The city of Vancouver without its urban fringe has the economic base to survive without Portland. It is more a sister city than a bedroom community. The government of the city is willing to cooperate fully with regional government and the city of Portland but does not want to be controlled by them. While the people don't mind being associated with the "Portland" Metro area, they have a distinct separateness. As an example, 
one of those interviewed felt that if someone from suburban Portland was 1,000 miles away and was asked where he was from, he might be likely to say "Portland, Oregon." A person from Vancouver in the same situation could be counted on to say "Vancouver, Washington."

Vancouver's Urban Fringe

It is difficult to determine whether the developed areas outside of the city limits of Vancouver are more suburbs of Vancouver or Portland. The common impression is that these fringe areas are more of a bedroom of Portland than the city of Vancouver is. The fringe also serves as a suburban residential area for the city of Vancouver. It should be noted that access to Portland, from these developed areas, is through Vancouver and over the single bridge.

The development of this fringe area is rather recent. Most of it has been developed since World War II. From 1960 to 1973 , there was a 37 percent increase in the population of Clark County. $\frac{13}{3}$ This fringe area was largely responsible for that rapid growth.

The fringe of Vancouver is concentrated in two areas, Evergreen to the east and Hazel Dell to the north. These areas are similar, although Evergreen is the newer of the two.

The problems that exist here are severe growth-related problems. This seems to be a prime area for young families to settle, and schools are over-crowded because the expansion of the district has not kept up with population. The development also has a number of apartment dwellings which tend to attract single-parent families. The concentration of young people in these suburban areas also tends to make evident the lack of recreation facilities. Along with these problems, come the problems of delinquency, family problems, drugs, and mental health.

Land use is a very hot issue. Sewer, water, and drainage issues are important; roads and transportation are also problems. Growth, until very recently, has not been controlled to any great extent. Residential growth has gone on without industrial development, causing a weak tax base from which to provide services.

Al1 of these problems have stimulated citizen participation. Reacting to the many problems in the communities and to threats to their personal well-being, people have begun to come together. There is very little community identity in these areas and there is no central city center or commercial district for people to identify with. Common issues and concerns, however, are beginning to establish some of the identity that was lacking. The Evergreen area has a community organization. It began as a reactionary group but has moved on to do some important work in community action oriented causes. There appears to be real potential in this area for good

13/ Clark County Health and Welfare Council, Social Profile of Clark Co. Prepared by Patricia S. Anderson, Vancouver, Washington, July 1972, Page 2. 
and effective citizen involvement. Another problem of the fringe area is that of the county having to provide services because these areas are nonincorporated.

The positive aspects of living in this area are the proximity to Portland and Vancouver, the nearby recreation facilities, and lower property cost than in many areas.

Its role in the Metro area is to serve as a residential area for both Vancouver and Portland. Growth is likely to continue in those areas, and it will increasingly become an area to be recognized. With the advent of the I-205 bridge which will bring that fringe and Portland closer together, the area is likely to become more and more a bedroom of Portland.

\section{Profile Data}

Following is a statistical summary describing the city of Vancouver and its urban fringe. One should note its similarity to the Willamette River communities. Its low to middle income range, housing value and low percent of non-whites are similar. The Vancouver area has a wide range in terms of age characteristics, having the tract with the highest mean percent of youth. 
Total Pop. 71,000

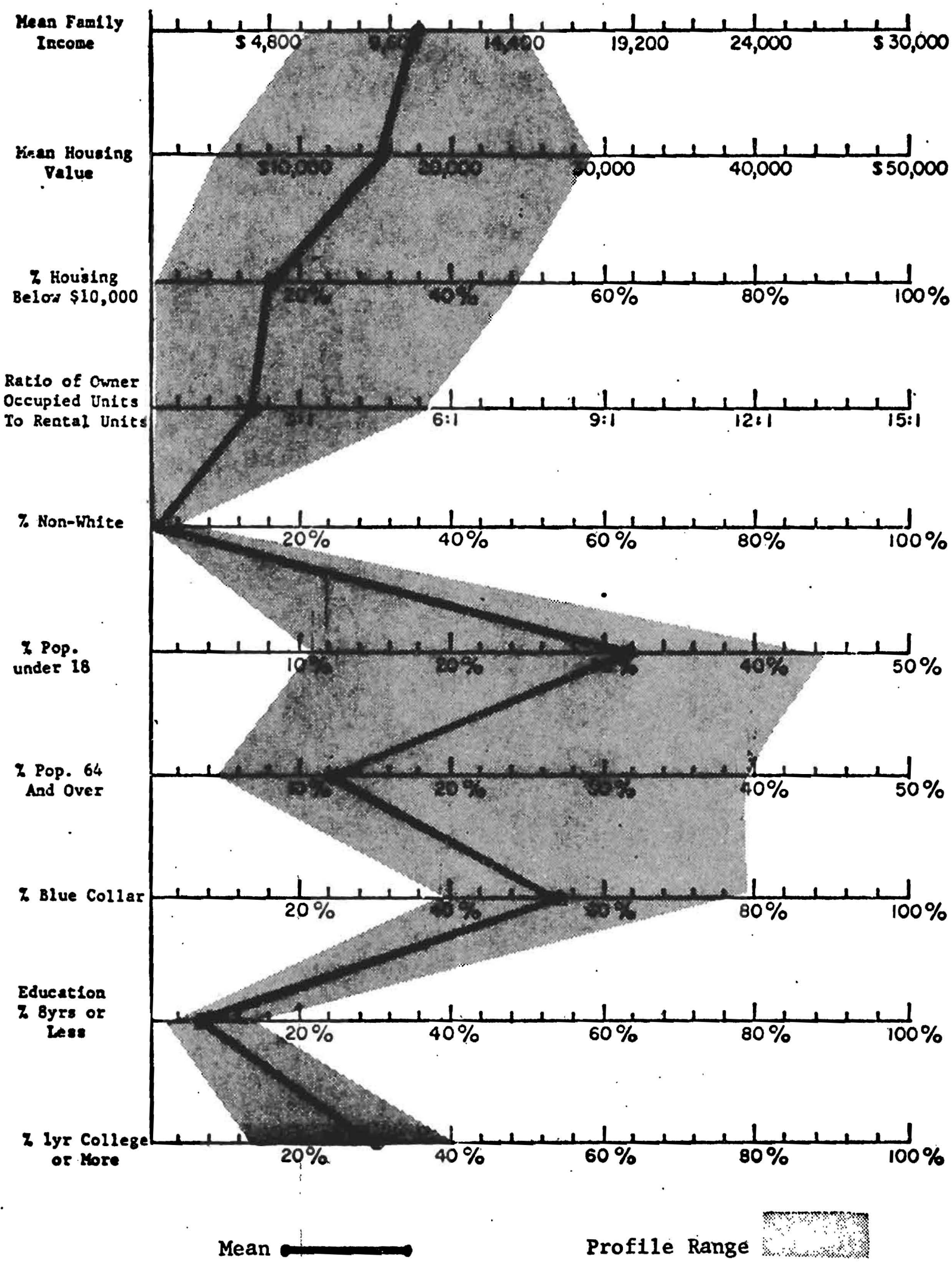


Mean Family Income ............ $\$ 10,773$

Mean Housing Value........... . 15,538

$\%$ Housing Below $\$ 10,000$. . . . . . . $16.68 \%$

Ratio of Owner Occupied

Units to Rental Units ......... 2.09:1

$\%$ Non-White . . . . . . . . . . $1.59 \%$

\% Population under 18 . . . . . . . . . $31.78 \%$

$\%$ Population 64 and over . . . . . . . 12.24\%

\% Blue Collar . . . . . . . . . . $54.00 \%$

Education,

$\%$ 8yrs or less . . . . . . . . . $6.91 \%$

$\% 1$ yr College or More . . . . . . . $30.15 \%$

* All statistics based on 1970 census data. Statistics in-, dicating dollar figures are substantially lower than present values due to inflation.

Education data covers males 20 - 49 years old and Females 15 - 44 years old due to availability of data.

The Profile Range represents the range of individual mean scores of the census tracts within the profile area. 
PROFILES 6 - 10

THE CITY OF PORTLAND

The following profiles take a somewhat different form from those concentrating on the area outside of the City. Unlike profiles one through five, little mention is made of the availability of community services. It is assumed that while at different levels of convenience, a wide range of community services are available in the city, which might not be available in all areas outside the city. Therefore, these profiles mention the availability of community resources only when abundance, or lack thereof constitutes a significant aspect of the community.

These profiles also are different in that, within each subarea, only three neighborhoods were selected (except North Portland which is described in two parts) to provide a description of the range of conditions which exist. 
PROFILE NO. 6

SOUTHEAST PORTLAND

\section{Overview}

The Southeast Portland area is a diverse and interesting area of the city. Made up of more than 16 neighborhoods south of the Banfield freeway and east of the Willamette River, it can be characterized as very heterogeneus. The individual neighborhoods, when studied, give a better idea about the Southeast. For the purpose of this report the Southeast is characterized as having three main parts, the inner city area, the upper socio-economic areas, and the developing or annexed areas. Although this does not include every neighborhood the parts represent the range of conditions which exist in the Southeast. One neighborhood from each part will be examined.

The first of the three parts is Inner Southeast, stretching along the Willamette and including the Buckman, Brooklyn, Hosford-Abernethy, Keins and Sellwood-Moreland neighborhoods. It is often referred to as inner city and has many unique problems and concerns.

\section{Buckman}

Within this Inner Southeast area the profile will examine the Buckman neighborhood. The following summary is based on interviews and observations of the Buckman area.

The Buckman area lies on the east bank of the Willamette from the river to 28 th street, bordered by Burnside on the north and Hawthorne on the South. Like much of the Inner Southeast it has a developed industrial and commercial area from about 12 th street to the River. Its access to the river is completely cut off by I-5 and a maze of bridges, ramps and rail tracks. East of 12 th the major arterials are developed as , commercial with residential blocks in between.

The Buckman Community Association started in 1968 and has participated in land use planning, was instrumental in securing Housing and Community Development (HCD) money and continues to work on other important local and Southeast issues. Citizen participation here is felt to be quite good. There have been many successful reactions of the community to threats and such reactionary organization has evolved an action orientation. This planning, and positive action has brought many programs and benefits to Buckman such as the HCD money.

There are many positive things happening in the Buckman area. People are buying individual properties and fixing up older homes. There is an influx of young people interested in improving the liveability of Buckman

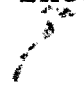


and willing to become involved. One gets the impression the flight to the suburbs has been stopped there. There is a growing number of services to the elderly who make up a large portion of the area's population and there is a growing identification with the neighborhood. Part of this identification has to do with a common feeling of resentment of the suburbs, typified by the stopping of the Mt. Hood freeway.

Buckman has the advantage of being very close to downtown, and has its own commercial and industrial area. Most community services are nearby although the area is lacking a nearby drug store. Those interviewed seemed to feel that people are optimistic about the future of Buckman.

There are still many problems in the area. Among them are the tearing down of houses to make way for apartments and expansion projects; a high rate of crime, and the closing of schools. Public transportation is a problem if one is going north and south. One of the main problems of the area is its age. Developed in the early 1900's its streets are narrow, lots are small, much of the housing is old. Much of the industrial area is also antiquated and could be redeveloped.

The occupational make-up of the area seems to be very mixed: there are white and blue collar workers, retired people and young singles. People have a growing concern that the inner city should not die and should not be over run by suburban traffic and freeways. As one interviewee put it, "if people want to work downtown they should live in and revitalize the inner city not turn it into one big freeway."

It is this type of growing community spirit which typifies the Inner Southeast neighborhoods. Their potential for both liveability and industry is. great.

\section{Eastmoreland}

Among the neighborhoods of higher socio-economic status are Eastmoreland, Laurelhurst and Mt. Tabor. These areas are located in separate areas of the Southeast but have much in common. Following is a set of impressions about Eastmoreland.

Built around Reed College, Eastmoreland is known as the Heights of the east side. It is one of the places on the east side where professionals and upper income people tend to live. Developed mainly in the 1920's its area is nearly filled. Very few vacant lots or homes are evident. This setting of a stable, well established area, with well-kept homes, tends to create a different feeling about problems. There are few real pressing issues. The community organization is issue-oriented but because few issues are present participation is low. Little need is felt for activist type involvement because of the contentment within the area.

This is not to say the people do not perceive there to be problems. Residents are concerned about traffic on their streets, bus service for north and south routes, about street lights and school issues. The issue of busing school children to other schools is a real potential threat to this neighborhood as well as to others. 
People in Eastmoreland seem to have political potency which helps keep their area pleasant and keep the activity of the neighborhood association down. One interviewee's opinion was that people in Eastmoreland are not in awe of politicians and thus when problems arise, they are apt to call someone they know at City Ha11. This way of dealing with problems seems to work for Eastmoreland. The community association is potentially strong for this reason and has been successful in most areas it has entered.

Most of the residents of Eastmoreland are happy with their area. They have easy access to the city, a highly respected college, and a quiet stable community. It is probably one of the most homogeneus areas of the city. Its social clubs, tennis association, and golf course all help give it identity. If one's object is to raise children exposed to many different life styles Eastmoreland is probably not the place to live.

Sometimes the other Southeast areas feel that Eastmoreland considers itself above them and is not interested in taking part in such groups as the Southeast coalition of neighborhood groups. Probably closer to the truth is the fact that problems, if not different, are at least perceived and handled differently in Eastmoreland. It therefore has little incentive to expend its energy on neighborhood coalition activities.

\section{SURGE}

In still-developing areas on the edge of the city, there are many unique problems. Neighborhoods like Montavilla and SURGE are still growing and changing.

SURGE (Southeast Urban Renewal Growth Endeavor) is the most southeastern neighborhood in the city. It was once the community Lents and was annexed by Portland. Its history of being a rural town brings it many problems today. The SURGE area was never planned as a city. It apparently had no building codes, or planning for streets or sewers. Today it is a fast growing area with new apartment buildings and developments but with poor streets, an inadequate sewer system, a high degree of substandard housing. The area has a strong blue collar low middle income orientation and has.many of the frontiersmen, individualistic characteristics of some of the outlying areas. Being a former outlying town and rural area it seems to retain many of the more conservative qualities. Those in community development report that citizen participation is $10 \mathrm{w}$, for many reasons, one of which may be that the family is the strong social institution and not. neighborhood or community groups.

As one of its positive points the area has a great deal of economic potential. The new I-205 will pass through SURGE and may bring new commerce. The people are beginning to organize and are drawing strength from other southeast organizations.

\section{Summary Southeast Portland}

Overall those interviewed felt that the southeast area of Portland has always viewed itself as "the step-child" of Portland; always second best. 
It is a melting pot of income levels, ethnic groups, long time residents and transients. Its neighborhoods have a variety of socio-economic status but all have two common bonds. One is resentment of the negative connotation often given to or perceived by the east side and second a resentment of the suburbs using their neighborhoods as a thoroughfare.

The Southeast has a form of citizen participation which is reactionary but being forced into being action oriented. Inundated by requests from many agencies to review plans and projects, community organization people are having an impact but wishing they had more expertise and manpower. People appear to be encouraged by the growing sense of neighborhood identity, and community organization strength was greatly enhanced by the defeat of the proposed Mt. Hood freeway. There is an optimism especially in the younger generations about the potentials of the area.

\section{Profile Data}

The following statistical summary describes Southeast Portland. The interesting aspect of this graph is the relatively narrow range in most of the characteristics. The only wide range is in the ratio or owneroccupied units to rental units. The percent of non-white population is the lowest for any area of the city. 
Total Pop. 156,861

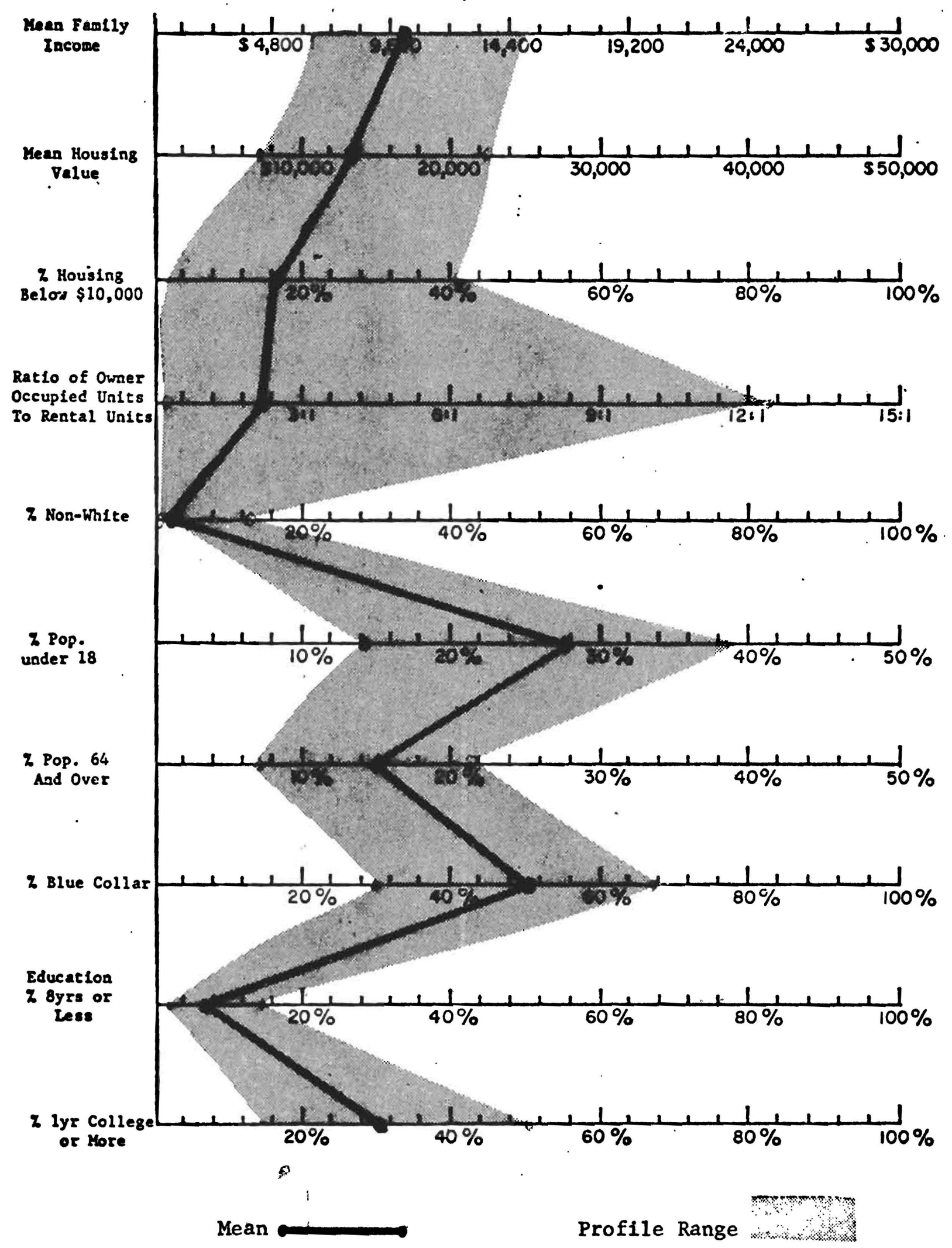


Mean Family Income . . . . . . . . . $\$ 10,325$

Mean Housing Value . . . . . . . . 13,493

$\%$ Housing Below $\$ 10,000$. . . . . . . $18.66 \%$

Ratio of Owner Occupied

Units to Rental Units .......... 2.15:1

$\%$ Non-White . . . . . . . . . $3.50 \%$

$\%$ Population under 18 . . . . . . . . $27.90 \%$

$\%$ Population 64 and over . . . . . . . $14.88 \%$

\% Blue Collar ............. 51.00\%

Education,

$\%$ 8yrs or less............. . $7.20 \%$

$\% 1$ yr College or More........... $31.02 \%$

* Al1 statistics based on 1970 census data. Statistics indicating dollar figures are substantially lower than present values due to inflation.

Education data covers males 20 - 49 years old and Females 15 - 44 years old due to availability of data.

The Profile Range represents the range of individual mean scores of the census tracts within the profile area. 
PROFILE NO. 7

NORTHEAST PORTLAND

Northeast Portland is that area north of the Banfield Freeway and east of North Williams Avenue. It has about 14 organized neighborhoods. Its heterogeneus population is spread across a rather small area. The area provides the greatest mixture of minorities and ethnic groups. Portland's Black population is centered in the Humbolt, Boise, King, Vernon and Woodlawn neighborhoods of Northeast. Communities of Irish, Ryssian, German and Finnish ethnic heritage can also be found in Northeast. 14 A wide range of socio-economic levels coexist here. Industry lines the northern border and the railroads line the southern border. Small industrial and commercial establishments center along major arterials leaving residential neighborhoods between. Northeast Portland has been the center of much change in recent years while it was under the model cities program.

This profile will also deal with three neighborhoods which seem to represent the range of what exists in the northeast area. The profile will examine a predominantly black inner city neighborhood, a neighborhood in transition in terms of liveability and an older stable white middle class neighborhood in the outer reaches of the city.

\section{Boise}

The Boise Neighborhood is bordered on the West by I-5, on the north by Skidmore, on the south by Freemont, and on the east by Rodney. There is a large amount of small industry and commercial activity especially along Union Avenue. The residential areas are populated by people of low to middle incomes, most of whom are black. Many of the problems of this area are reflected problems of discrimination and unemployment.

Citizen participation moves with the issues; presently there are few immediately threatening issues and thus rather low participation as seen by neighborhood leaders. Those interviewed gave several reasons why participation is low. First there is said to exist a psychological factor which makes blacks and poor people, black and white, feel they have no influence in government. Another reason offered was the occupational structure. The great majority of those who work have blue collar jobs and thus little time and energy to devote to a neighborhood organization. Despite these reasons the neighborhood organization does exist and a sma11 core of people keep it folng. It has been active in the model cities program, Housing and community development programs and in developing land

$14 /$ CUE Report, Center for Urban Education Bulletin, "Preliminary Report on Portland's' Ethnic Heritage," Spring, 1976. 
use plans. And though citizen participation is low at most times, people have a growing awareness that they can have some effect in the decisionmaking process. They demonstrate this by large turnouts to public meetings and hearings when a specific issue arises. This was almost unheard of ten years ago.

People are encouraged by this growing awareness. Practice in Model Cities planning helped give people the courage and confidence to speak out at meetings and express opinions. With this growing awareness and the accomplishments of the neighborhood group through Model Cities and HCD moneys there is a growing community pride and identity. Such things as clean up fix up projects and increased citizen participation reflect this.

Community leaders felt there were several problems in the community, mainly centering around social needs. Discrimination in jobs, unemployment, crime and prostitution were mentioned social problems. One problem associated with hindering community identity was the apparent large number of absentee land owners. These as well as other problems such as land use and traffic also affect the remaining inner Northeast neighborhoods.

The local community organization has now become well enough known that people tend to use it to solve problems when they arise. This is one growing strength of the area. Other things the area has going for it, mentioned in interviews, were proximity to downtown and industrial centers, affordable homes, and the potential of being an investment area.

Leaders felt the need for jobs, recreation, information coordination, improved housing and schools. Overall it was felt that people had mixed emotions as to the future of Boise and the inner Northeast.

As a role in the Metro area, this area provides low rent housing for elderly and low income people and a commercial area used mainly by its own residents. The part it plays in city decision-making is centered around its own area.

\section{Irvington}

The second area of consideration is Irvington, located north of Broadway and bordered by $7 \mathrm{th}, 26 \mathrm{th}$ and. Fremont. It is a neighborhood in transition. Ten years ago it was a middle class neighborhood suffering from the flight to the suburbs and deterioration. Largely due to the efforts of the neighborhood organization and model cities programs it has once more become a stable community and an attractive place to live.

Although surrounded by commercial areas, Irvington is almost entirely residential. The streets are quiet and tree lined and most houses are well kept. As a part of revitalizing the area, rezoning was passed to keep the single family residential quality. Irvington has now become so attractive that in the past two years real estate values have almost doubled, older homes are being bought and fixed up, and residents are becoming active in preserving the liveability of their neighborhood. 
The community organization is seen as a strong one. Its focus is on preserving liveability and is doing so by reaction to issues and active planning when called on to do so. People are happy with the growing stability of the neighborhood, the increased real estate values and home improvements. There is also an optimism about the integration in this area. Many middle class blacks are finding Irvington a pleasant place to live.

The problems of this area are largely common to inner city areas. They are traffic on residential streets, crime, school issues, and land use as it has to do with expansion of business. People deal with these problems differently. Some contact local officials directly. It is felt that a number of city hall folks live in Irvington, which increased the line of communication and thus political potency. Many people use the community organization. Its successes are well known and its communication with the residents is thought to be good.

The area has, among its positive elements, large homes, convenient shopping at nearby Lloyd's Center and easy access to downtown. It lacks community and social services, especially for senior citizens. Most of all the area lacks a united identity. Irvington's southwest corner has little identity with Irvington and has little citizen participation. Overall, people were characterized as optimistic in terms of the future with an element of having reached something to hold on to.

This mainly white collar, residential area provides a most interesting example of a neighborhood which has been in transition and whose citizens have taken part in that transition.

\section{Concordia}

The third area of consideration in the Northeast is Concordia. It is an example of a stable white middle class neighborhood outside the inner city area. It takes its, name from the small Lutheran College located there. It is mainly a residential area with its northern boundary lined with industry. It is located west of $42 \mathrm{nd}$ and North of Prescott.

Concordia's citizen participation takes on a quality of being issue oriented. The local organization has had difficulty in getting people involved in action oriented activities, and core of individuals do a majority of the work in the organization. One issue which did rally citizens was a sewer problem. The people were successful in securing a new sewer system. People are generally concerned with neighborhood beauty and liveability, about crime, and services for senior citizens, and they like to see things like the solving of the sewage problem, quality education and community projects. There do not seem to be pressing issues. There is some fear of an influx of minorities and the future may bring into focus prejudices which it has been suggested exist there.

Concordia has many things going for it, mainly stability. People living here for a long time tends to give Concordia an identity. The area is primarily residential with little noise or pollution and except for one of the highest crime rates in the city it is a pleasant place to live. 
In the eyes of those interviewed it lacks citizen participation and adequate police protection. The feeling was that few other things were lacking.

Sources reporf people using many means of solving problems. from letters to the editor of the local paper. The Community Press, to calling the leader of the neighborhood organization. One weakness of the Concordia organization is its lack of participation in the Northeast coalition of neighborhoods. Like Eastmoreland in Southeast it is a content area and does not have a pressing need to be a part of such a coalition.

Overall the residents are reported to feel things are pretty good in their neighborhood and have no reason to worsen. This mixed white collar and. upper middle income blue collar area provides a quite stable neighborhood, not exclusive, but comfortably middle class.

\section{Summary}

In summation, the Northeast provides a wide range of neighborhoods, Degree, quality and expertise in citizen participation vary as widely as the type of neighborhood but certainly with an apparent correlation. Those neighborhoods discussed do not represent every neighborhood in the Northeast but attempt to show the variety in NE neighborhoods. Again it should be noted that these profiles are impressions and observations taken from personal interviews with community leaders.

\section{Profile Data}

The information which follows is the statistical description of Northeast Portland. Of special note is the wide range of the percent of non-white population, the percent of housing valued below' $\$ 10,000$ and the ratio of owner occupied to rental units. Great variation exists between the census tracts on these characteristics. As suggested in the text the non-white population of Portland is centered in a few neighborhoods in Northeast. 
Total Pop. 85,760

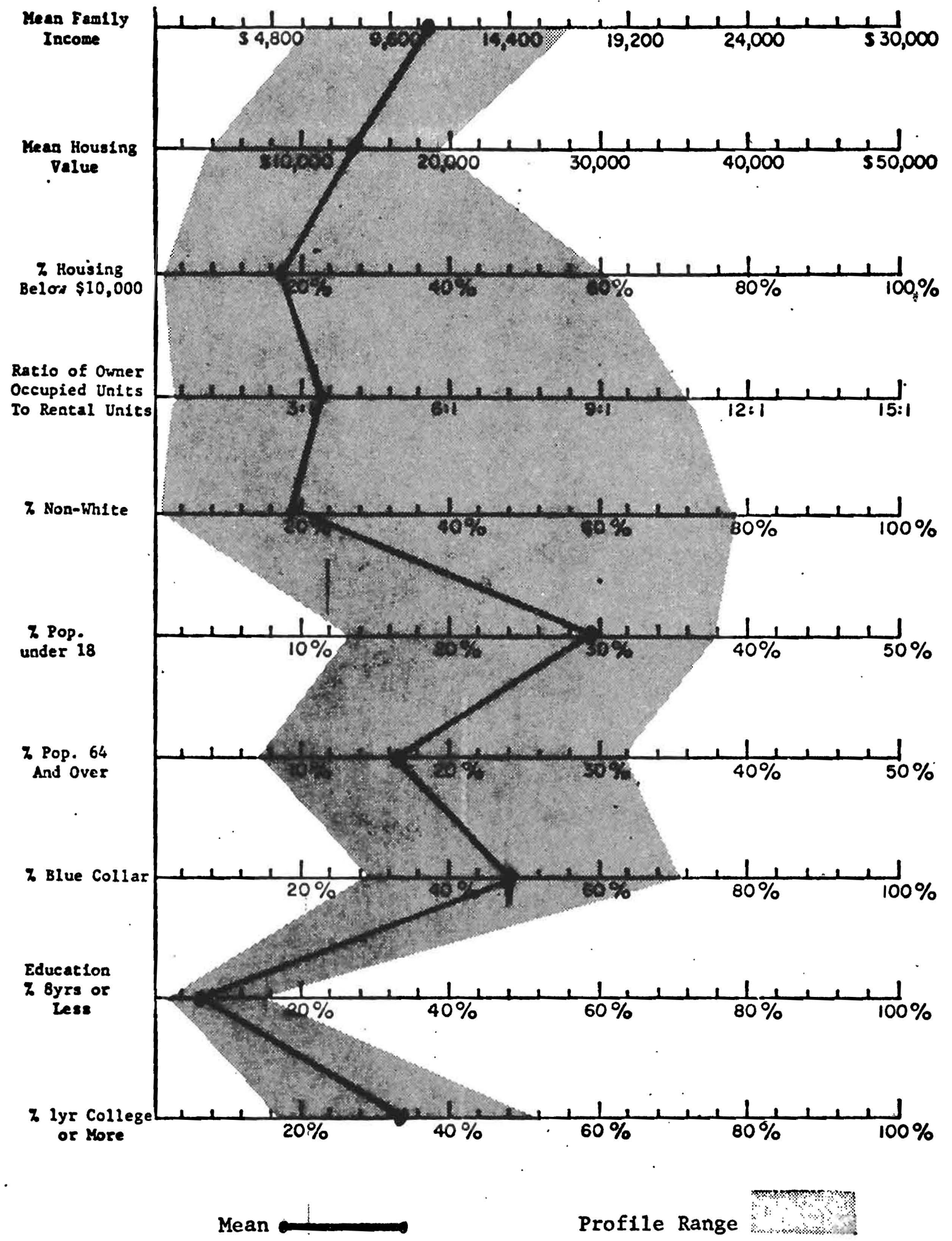


Mean Family Income . . . . . . . . . . $\$ 11,016$

Mean Housing Value . . . . . . . . . 13,553

$\%$ Housing Below $\$ 10,000$. . . . . . . $17.22 \%$

Ratio of Owner Occupied

Units to Rental Units ......... $3.45: 1$

$\%$ Non-White . . . . . . . . . . $18.78 \%$

$\%$ Population under 18 . . . . . . . . $29.61 \%$

$\%$ Population 64 and over . . . . . . . . $16.69 \%$

$\%$ Blue Collar .............. . 4 $48.00 \%$

Education,

$\% 8 y r s$ or less . . . . . . . . . . . $6.83 \%$

$\% 1$ yr College or More . . . . . . . . . $33.82 \%$

* A11 statistics based on 1970 census data. Statistics indicating dollar figures are substantially lower than present values due to inflation.

Education data covers males 20 - 49 years old and Females 15 - 44 years old due to availability of data.

The Profile Range represents the range of individual mean scores of the census tracts within the profile area. 
PROFILE NO. 8

NORTH PORTLAND

\section{Overview}

North Portland is an area often neglected and a very distinct part of Portland. It is that area west of North Williams Avenue to the Willamette River and north to the City limits, and to include Linnton across the river. It, unlike the other areas already described, does not have as many organized neighborhoods. Instead it has two recognizable parts the Inner North which includes all the area southeast of the St. Johns railroad cut, and the area known as St. Johns (including Linnton). These two areas have many different characteristics although the entire North Portland area has an identity all its own. One community organization serves the entire area and though there are six or more separate neighborhoods, they seem to be only one.

The overwhelming commonality of North Portland is its "Blue Collarness." It was described in one interview as the "working man's area" of Portland. This aspect of the area has a great deal to do with the kind of problems and the way people deal with those problems. The area includes the Swan Island industrial area, the Rivergate industrial area and is just across the river from the Northwest Industrial area. Rimmed with industry on all but the east side, the area is mostly residential with the exception of major arterials and the St. Johns business district.

\section{Inner North Portland}

Inner North Portland includes the University Park, Kenton, Portsmouth, and Overlook neighborhoods. They are each different but have many similarities. Following are some impressions of those communities by community residents and leaders.

The quality of citizen participation in Inner North Portland is felt to be good. The organization there is active with a range of accomplishments, . and there appear to be as many action oriented concerns as reactions to problems. It appears that although people are in blue collar occupations they find time to at least be aware of the community organization. Many wives of working men take an active role. Most residents show their support and approval of citizen participation by calling on the organization for help with problems.

Issues that people are concerned with range from social problems such as race relations, prostitution, crime and welfare, to economic and physical concerns such as jobs, taxes, streets and control of placement of industry. The area is felt to lack adequate medical facilities, adequate low income 
housing, good bus service and adequate police protection. Interstate 5 creates a great traffic problem which spills over onto North Portland streets. The government housing authority project known as Columbia Villa has been a "no man's land" in terms of crime. Despite its problems the area has several strengths.

This area has going for it nearby industry, access to jobs and downtown. It has a large University. Most important, it has a solid stable blue collar work force. People reportedly buy homes and stay there the rest of their lives. This seems to create a strong self interest in community and thus a base of support for a community organization.

While the area is mostly middle income there are pockets of wealth and of poverty. Both exist in the area in the midst of a North Portland philosophy, or mentality which believes strongly in the system of capitalism and the work ethic. This "American Dream" conservatism is sometimes a source of tension between socio-economic levels. Despite this feeling many different groups in the community do coexist.

St. Johns

St. Johns and Linnton make up the area defined as outer North Portland. The following impressions will focus on St. Johns but are applicable to Linnton as well.

When one drives into St. Johns it is like entering a different city, which St. Johns was until annexed by Portland. With its own City Hall, business center and the classic S.t. Johns Bridge the area is apart of the rest of the city. It is geographically separated from the rest of North Portland by a rail line canyon, and impressions of the area indicate that St. Johns is still very independent of the City of Portland. Its identity is such that when a resident speaks of going downtown he is speaking of downtown St. Johns. When going to downtown Portland he would speak of going to the City. This small community has a history and tradition all its own.

Problems in St. Johns are centered on preservation of the business district, street improvement, housing deterioration and surrounding industrial development. These problems are dealt with mainly through the community organization. The North Portland Citizens Committee which serves all of North Portland has brought many benefits to the St: Johns' area. These include HCD monies, and the Cathedral Park project plus several others. Well rounded, this community lacks only a large medical facility.

St. Johns seems to have the same kind of frontiersman', workingman's climate as was found in many of the outlying areas. Interviewees indicated that this has made St. Johns a strong community.

\section{Summary}

North Portland is an area often forgotten by Portlanders but it is a colorful and interesting area. The quality of its people lends itself to active community organization. Problems exist but yet all but the very poor have some degree of optimism. Pride is seen as a strong characteristic. Isolation from the city is more perceived than real but it lends itself to a unique identity. 


\section{Profile Data}

The following is descriptive data concerning North Portland. One should note the high percent of Blue Collar workers residing in this area. Also of special notice are the ranges of percent non-white and ratio of owner occupied to renter occupied units. The range of the latter was beyond the scale of the graph. This area also has the smallest percent of population with at least a year of college and the highest percentage of less than high school education. 
Total Pop. 58,069

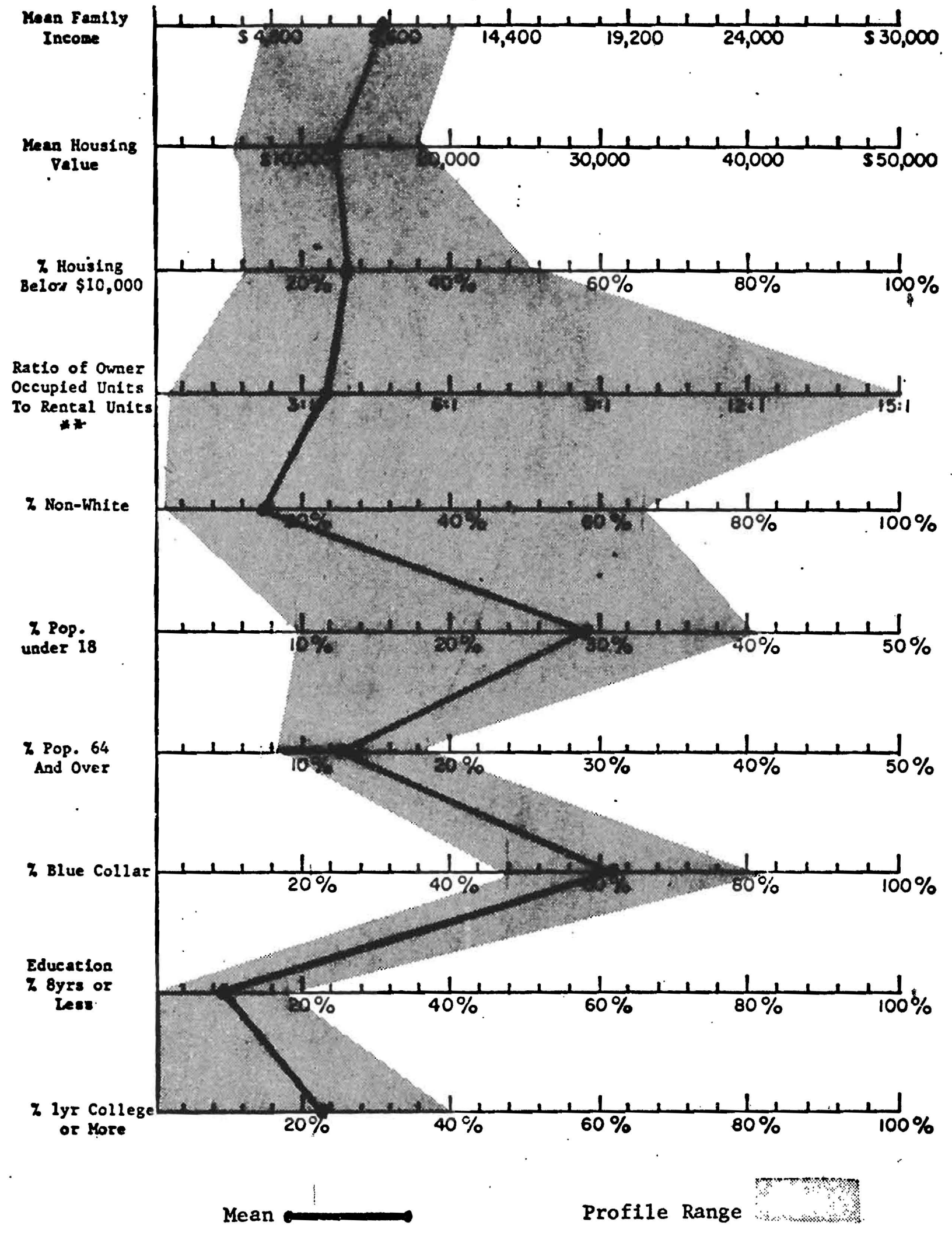




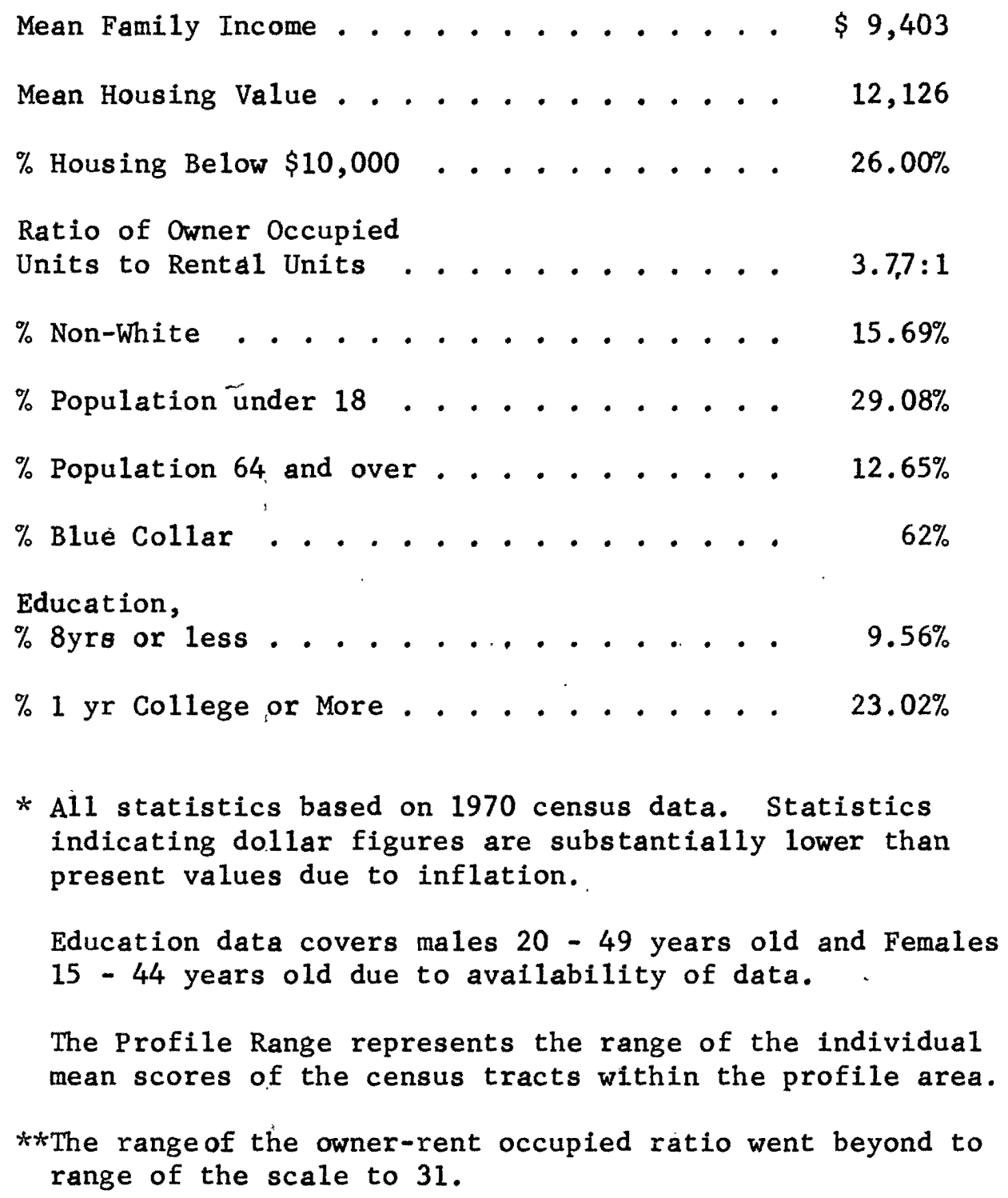


PROFILE NO. 9

NORTHWEST PORTLAND

Northwest Portland covers the smallest populated geographic area of the five divisions of the city, that area west of the Willamette River and north of Burnside Avenue. The Goosehollow area, Forest Park, the Northwest Industrial area, the Northwest flats, and the Burnside district are the neighborhoods considered to be in NW, even though the Goosehollow a rea extends on both sides of Burnside. Each of these neighborhoods is distinctly different from the others, having unique characteristics, identities, and problems. A combination of distinct neighborhoods makes Northwest an area of the city which attracts a wide range of people from many different backgrounds.

This profile will look at two areas of Northwest Portland in depth and briefly describe the remaining areas. The descriptions here, as in the other profile, are the impressions of those interviewed, not necessarily facts.

\section{Burnside}

The first area is Burnside. At the north end of downtown, it extends north and east of Burnside to the Willamette River, and west to Park Avenue. It. is an area of cheap hotels, flop houses, older businesses, taverns and specialty shops. It is said to be the center of the Chinese population and many of the city's Native Americans can be found here. Burnside Avenue is the Skid Row of Portland. Alcoholics, hobos, and lonely old men occupy the cheap housing. There are few owner occupied dwellings.

Because of its uniqueness, the problems of the area are unique. The local community organization, Burnside Community Council, is made up primarily of absentee landlords, service agencies, and businesses. Few of the area residents take part, although there are some residents involved. The group does see itself as active and believes it has the residents' welfare in mind.

The problems in this area have to do with landlord-tenant relations, alcoholism, substandard housing conditions, police protection, unemployment, and lack of access to recreation. Few of these problems are dealt with by the residents. The city and private agencies provide some positive additions to the area. Halfway houses, alcohol treatment programs, and the Salavation Army are positive points. HCD monies have brought some improvements in housing. An interesting strength of this community is the * Transient Bank. This is a bank established especially for the transient population. It is known to many as the Hobo bank. 
Because the problems are so different here, there is an entirely different way of handling them. Most residents depend on agencies for assistance. Land owners and businessmen rely on the community organization and personal contacts.

Opinions vary on whether things are getting better or worse. Most agree that physical things are getting better: businesses are being revitalized and agencies are available to residents. However to the resident who wants only a flop house to sleep in and a street to drink on, community improvement gives him no place to go. From his point of view, better is worse.

Northwest F1ats

Northwest Flats, known as the Flats is also a unique area. It is located North of Burnside to Nicolai Avenue and West of I-405 to the base of the hills. If indeed there is a melting pot neighborhood in Portland, this is it. old people, young people, families, singles, minorities, ethnic groups, professionals, blue collars, artisans, poor, rich, liberals, and conservatives all can be found here. It is the most densely populated area of the city and contains a mixture of single family dwellings, multiple family units, and apartment structures. Most of the housing is older and there are few vacant areas. The neighborhood is close to downtown, has ample recreation areas, and has an identity as a neighborhood. It, unlike most of the city, is an area in which it is not necessary to have an automobile to get around.

Its local neighborhood association started more than six years ago to stop the expansion of Good Samaritan Hospital and other projects. It successfully fought the I-505 freeway and has been a strong force in keeping the neighborhood intact. As with other areas of the city, success in dealing with problems has helped a strong organization to evolve. Citizen participation in this area is reported to be high. The Northwest District Association also puts out a local paper. Most local problems, such as land use, some social need, housing improvement and neighborhood planning, are handled through the neighborhood association. Community pride is growing with community identity. People seem to have a feeling of optimism about their area becoming an even nicer place to live.

Goosehollow, Forest Park, and NW Industrial

Goosehollow and Forest Park are two areas of more single family units, tending to be much less densely populated and have higher income. Community organizations are rather new, especially in Forest Park.

The Northwest Industrial area is mainly that, industrial. Stretching along the bank of the Willamette, from about Broadway north to Linnton, it takes up a large area. This neighborhood is concerned with land use, traffic, and transportation issues. It seems to have an effective neighborhood organization which represents industry and residents and is taking an action-oriented approach to problems. 


\section{Summary}

So many distinctly different neighborhoods exist in Northwest Portland that it is unfortunate that each could not have been discussed in depth. The scope of this profile prohibits that. Northwest Portland is an active place in terms of citizen's participation. It feels it is a model for other places to follow. Its combination Skid Row, industry, inner city neighborhoods, and Forest Park make it an unusual place packed into a small area.

\section{Profile Data}

Following is a brief statistical description of the Northwest Portland area. Most prominent in these figures is the range of mean incomes. The census tract with the highest mean income of the entire study area is located in a NW neighborhood. This is not in line with the common belief that the Southwest has the most affluent neighborhoods. It does however indicate the heterogeneity of NW Reinforcing this also is the wide range in age and employment characteristics. 
Total Pop. 20,930

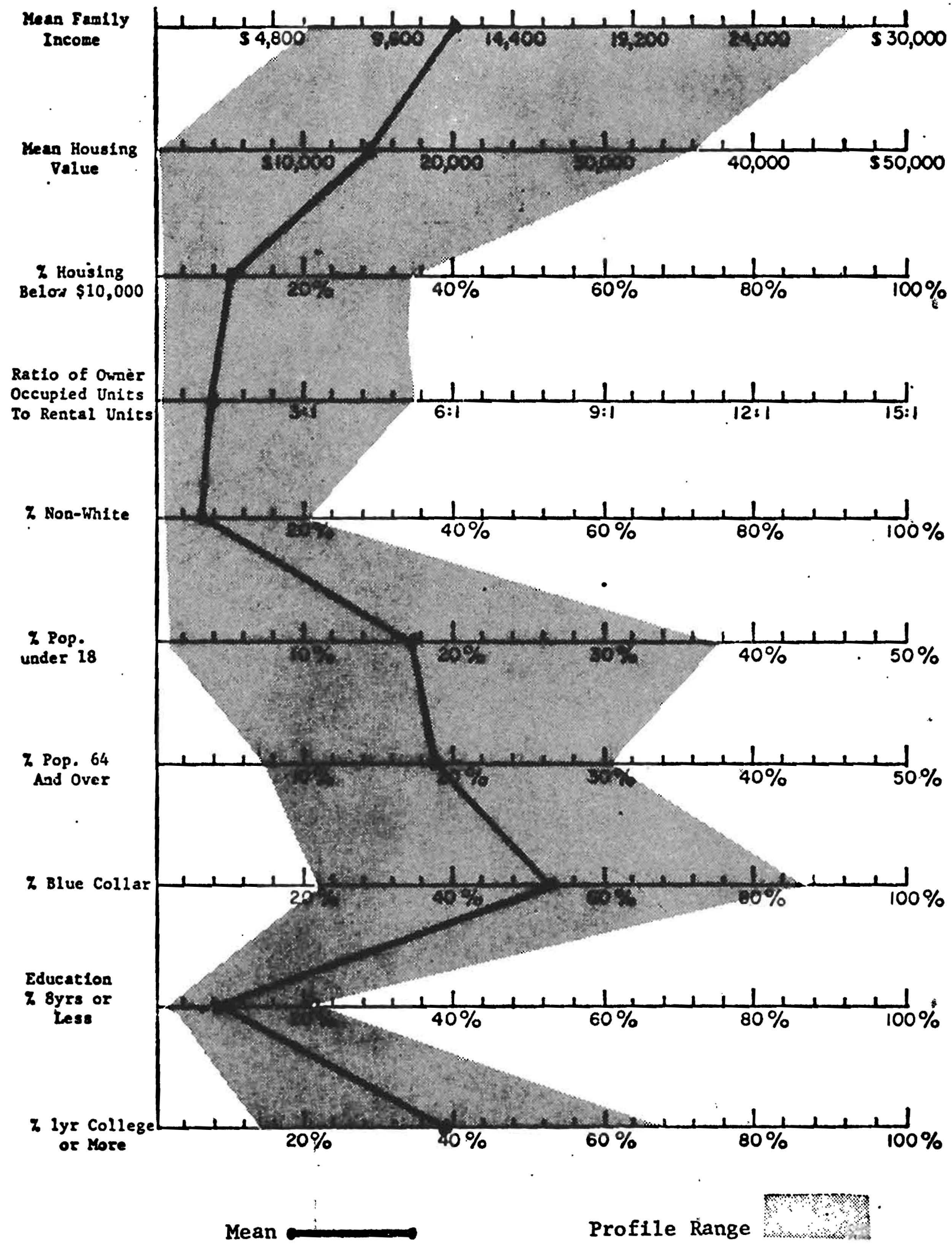




\footnotetext{
Mean Family Income . . . . . . . . . $\$ 12,295$

Mean Housing Value . . . . . . . . . 14,342

$\%$ Housing Below $\$ 10,000$. . . . . . . $11.16 \%$

Ratio of Owner Occupied

Units to Renta1 Units . . . . . . . . 1.22:1

$\%$ Non-White . . . . . . . . . $5.34 \%$

$\%$ Population under 18 . . . . . . . . 17.63\%

$\%$ Population 64 and over . . . . . . . 18.92\%

\%"Blue Collar .............. . . 53\%

Education,

$\%$ 8yrs or less.............. . . $8.46 \%$

$\% 1$ yr College or More . . . . . . . . $39.27 \%$

* All statistics based on 1970 census data. Statistics indicating dollar figures are substantially lower than present values due to inflation.

Education data covers males 20 - 49 years old and Females 15 - 44 years old due to availability of data.

The Profile Range represents the range of individual mean scores of the census tracts within the profile area.
} 
PROFILE NO. 10

SOUTHWEST PORTLAND

Southwest Portland 1ies west of the Willamette and south of Burnside Avenue. It is made up of several small neighborhoods and has more than ten organized neighborhood organizations. Like Southeast, this area covers a large area with many distinct neighborhoods. Even more clear cut than in Southeast, there are three distinct types of areas: Inner Southwest, the Southwest Hills, and outer Southwest. One neighborhood from each area will be examined. It is hoped that these three neighborhoods will represent the range of what exists in Southwest.

The important aspect of the Southwest is its geography. Built mainly on hills and valleys, except for downtown, the geography tends to separate and to isolate neighborhoods even when the distance between them is not. great. There is no Southwest coalition of neighborhoods, but the inner neighborhoods do work closely together.

\section{Corbett-Terwilliger}

Corbett-Terwilliger is one of the inner Southwest neighborhoods. It is older, very active and is felt to have a strong identity. It is located between the Willamette and Barbur Blvd. One interviewee expressed a feeling of being one big extended family. It is an area where almost everyone knows everyone else. It's filled with ownerwoccupied homes whose owners stay around a long time. One interviewee stated that they never knew the true meaning of the concept of neighborhood until they moved into Corbett-Terwilliger. With the exception of apartment developments, which most people feel are an intrusion on their values, there is an unique bond between the residents. This is probably the most close-knit neighborhood in Portland. Because of this closeness, informal communications are good and the degree of citizen involvment is described as high. People have been community oriented for many years. Neighborhood House, which provides many local recreation and social services, has been in existence for many years. People are now using the community organization to develop land use plans, to check pollution, and to solve traffic and transportation problems. Other problems in the community are high taxes, parking, and housing. The main threat is being overrun with apartment complexes.

Corbett-Terwilliger is a battered neighborhood. Three times major highways have chopped it up. Front Avenue, Barbur Blvd, and I-5 all pass through this area and each took its toll. The area lacks recreation facilities, access to the river, a local commercial area, and entertainment. Because it lacks these things and is cut off from the city by major highways it is almost a necessity to own a car. This presents a hardship for many older residents who make up about one-third of the 
population. The area of John's Landing tends to be a sore point with local people. As a nearby commercial establishment, it does not provide the kind of shops suited to the middle to lower middle class budgets of those in Corbett-Terwilliger. It too is perceived as an intrusion on values. It is a place where the affluent of the city can come and shop but not the local resident.

With all the problems that face this area, its strength lies in its people. They seem to work together, help each other, and together have the potential of a strong community organization.

The Corbett-Terwilliger area is mainly residential, planted on hills and valleys, and cut up by major highways. It is reported that traditionally this was a blue collar area but today it is somewhat mixed. One plus in the area is an upcoming young generation with a strong community identity, willing to work to preserve the area.

\section{Jackson}

The outer area of Southwest has many of the same problems of outer Southeast. The Jackson neighborhood covers a large area south of Multnomah Blvd, and Spring Garden Rd., crossing city and county boundaries. Its main problems center around sewers and land use. People, as in many fringe areas, are concerned about developers coming in. Much of this area has large lots and is almost rural. People want to preserve this kind of environment and yet have city sewers. Extensive development in some of this area is unlikely because of the topography: much of the area is unsuitable for development.

Citizen involvement here is mainly issue-oriented. Because much of this area has been settled since 1950, there are the same problems with growth and development as in suburban areas. Much of this area lacks sidewalks, sewers, lighting, parks, and playgrounds. Residents have mixed feelings about getting these services as they fear further growth. Citizen groups are often divided because of this.

Among the area's reported strong points are ruralness within the city, a tendency to be stable, youth, and a high degree of expertise from which the community can draw. There are mixed feelings on the growth issue. Many who stand to gain welcome it. Those who wish to preserve the liveability want to prevent it.

The part that this area plays in the city is residential. Commercial areas are limited to Barbur Blvd, and a few other concentrations. It is one of the few potential growth areas within the City of Portland.

\section{Southwest Hi11s}

The Southwest Hills area of Portland is the most affluent neighborhood in Portland. Median income ranges over $\$ 15,000$ and the homes in the area reflect this income range. placed on the hills overlooking the city, it is an attractive place with mostly older, expensive, well kept homes. 
Stability here is a very strong point. Many second and third generations of families stay in the same neighborhood. It is quiet. Its residents feel there are few, if any, social problems and when problems do arise they are handled on an individual basis.

The same tends to be true of community problems. Individuals often have the communication links to solve problems on an individual basis. The local community organization, the SW Hills Residential League, tends to involve itself in more general issues: land use and comprehensive planning are its major target areas. Its philosophy is to preserve the liveability of the SW Hills and to have great an influence as possibile in preserving and upgrading the liveability in the rest of the city. Citizen participation is somewhat low, as this responsibility is delegated to the core who run the community organization.

The neighborhood is reported to be encouraged by this type of planning. It finds satisfaction in being able to hire experts and draw from the best resources in the city. There seems also to be a definite community identity of people in the SW Hills. There is a sense of optimism. Things are very good and going to get better.

Neighborhood leaders felt the only weak point of the area was apathy, caused by an over-contentment with life style. A definite feeling of being the "nicest neighborhood" in Portland exists here and there is little that presently threatens this community.

Almost entirely white collar, upper middle, to upper class, this area serves as an affluent residential area.

\section{Summary SW}

Like the other sections of the city the SW is diverse. An unusually attractive part of the city, its residents love its liveability, and others see its growth potential. Downtown, which is in SW, was not profiled here. It is an interesting area which deserves further study.

\section{Profile Data}

The following is a presentation of statistical data concerning Southwest Portland. As indicated in the text this area has the highest mean family income in the profile area. Housing values, show the widest range of values as well as the highest mean. As within the NW the graph shows a wide range of income levels, age characteristics and percentage of blue collar employment. 
Total Pop. 65,770

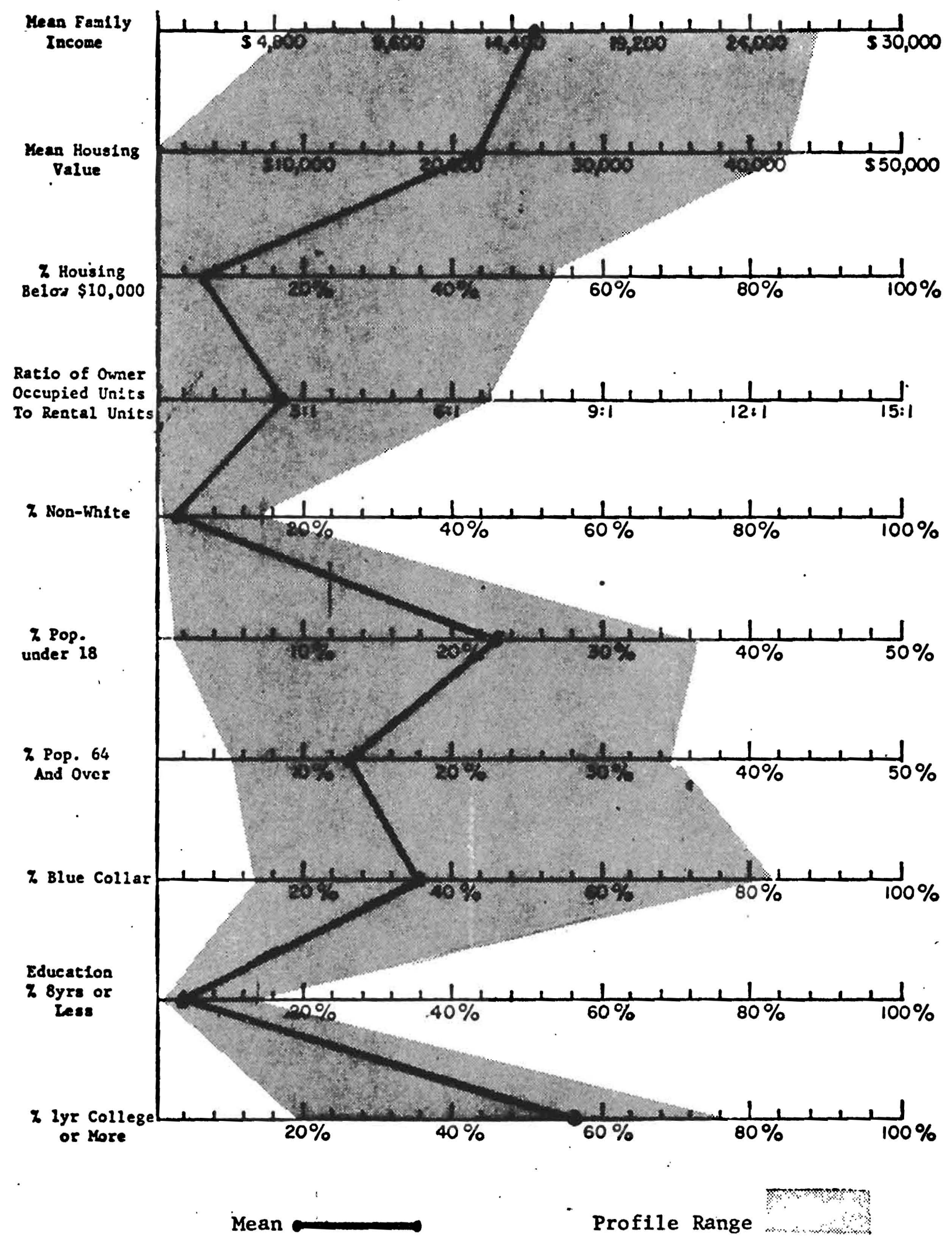




\section{ACTUAL MEAN SCORES}

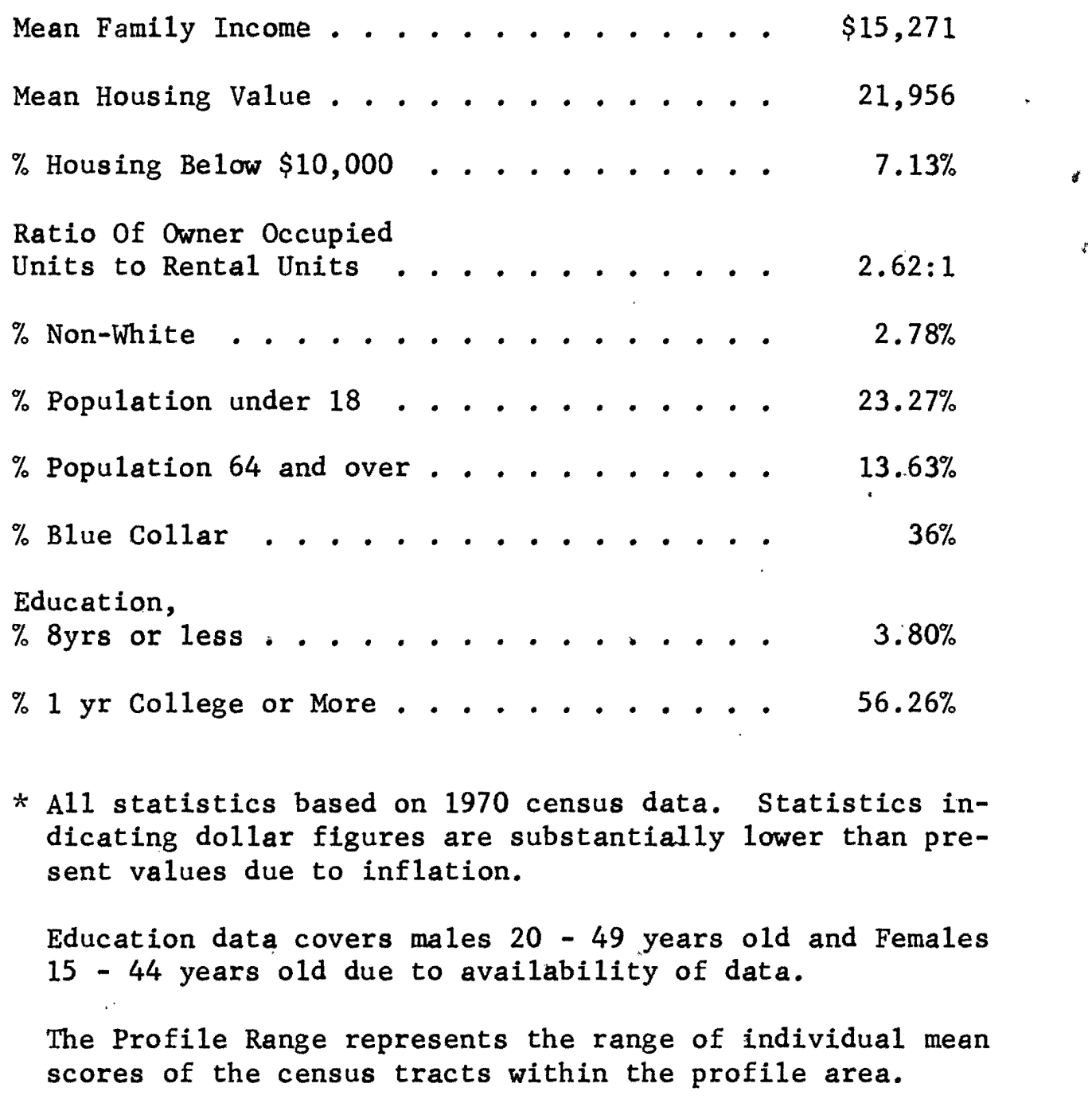


The issue of land use is so ubiquitous and yet so ambiguous that it desires further attention. Mentioned in most of the Profiles as a prime issue which concerns people, it becomes important to understand different viewpoints on the issues.

The present controversy over land use has its beginnings in the history of Oregon. The population is made up in part by the frontier stock and in part by the more recent immigration. This combination brings a strange paradox in state legislation, very progressive and liberal in some areas, yet very conservative in other areas. One area which has historically been judicious ly guarded in Oregon is the right of the individual. Historically, oregon has also been known for its beauty, grandeur, and clean air. Today there is an effort to preserve this aspect of Oregon. These two priorities do not always go hand in hand.

Recognizing that uncoordinated use of lands threatens the environment, the health, safety, prosperity, and well-being of the people of Oregon, the State Legislature enacted in 1973 the Land Use Act. This act set up the Land Conservation and Development Commission (LCDC) with the task of statewide comprehensive land use planning plus coordination and management of growth. The body was to identify priorities, establish standards, and initiate citizen involvement for the development of land use plans.

The concept that Oregon should guard against becoming a carbon copy of Southern California has been well received. Most also agree that planning is a means to prevent the problems suffered by many developed areas. However, in the application of the concept, LCDC has run into opposition at every turn.

The conservative frontier element of Oregon strongly opposes LCDC on the basis that it violates an individual's freedom to do whatever he may desire to do with his land. The businessman opposes LCDC because it limits his ability to create developments and thus profit. The farmer at the fringe of the urban sprawl opposes LCDC because it may prevent him from subdividing and retiring on the profit while at the same time trending (raising of tax valuation due to the proximity of development) raises his taxes. The person in the urban fringe area opposes land use plans which seek to urbanize his three-acre rural America.

In short, a concept which seems good for everyone collectively in practical application has satisfied almost no.one. People are not anti-planning. They are individualistic and self-oriented. Whether guided by independence or vested interests, people are opposing being told what they can and can't do with their land. So adamant is the opposition that the emotion tends to cloud the benefit which land use planning offers to everyone. Those who support land use planning also tend often to be more self-oriented. The wish to protect land values and to close existing communities to "undesirable elements" twist the original intent of LCDC. The issue is an emotional one and is important to each of the profile areas. 


\section{Citizen Participation}

The degree and quality of citizens participation in the decision-making process of local government and community affairs was a major topic discussed with each of the respondents. Some background on different types and qualities of involvement will aid the reader in interpreting comments on this subject.

Not a new concept in Oregon, citizen participation reaches into the operation of governments, special service districts, planning, and many other areas. Historically Oregon was one of the first states in which voters had the power to recall public officials, check state legislation by public referendum and directly elect U.S. senators. These and other laws and policies have fostered active participation in government decision making. As bureaucracy has grown and decision-making processes have moved farther away from the people, the inability of local government to respond to local needs has grown. Citizen participation has become a natural and necessary instrument in the decision making process.

New laws such as Oregon's Open Meeting Law and Public Records acts have helped citizen involvement by creating access to governments. In 1973 the land use law gave a boost to citizen participation, as it requires that citizens be involved in creation of comprehensive plans.

A vast number of citizens advisory boards, commissions, councils and organizations represent another form of citizen involvement. Political activity, regional, and issue interest groups constitute still other forms of participation.

In general but not in every case the type of citizen participation referred to in these profiles is the type in which people have formed community or neighborhood organizations. These organizations have either been organized because of state law or in many cases because people have rallied themselves around some local issue.

The quality assigned to participation in each area in the narratives is merely the impressions of the respondents as to the degree and quality of participation. For that reason descriptions of high and low participation should not be compared across profile areas. 


\section{CONCLUS IONS}

This research project has turned up many impressions of the area studied. Following are the researcher's conclusions.

The flexibility of the topical discussion approach, and the rather small sample draw, do not lend themselves to drawing conclusions about the many areas. The lack of uniform information between areas inhibits the formation of comparisons across areas. Though commonalities exist in strengths and weaknesses, issues, roles, and citizen participation it is impossible to suggest correlations between certain areas and certain characteristics.

The history of each of the areas profiled was intended to give a perspective to the present. Unfortunately, the time constraints of the project confined exploration of historical information to a minimum. That historical perspective which is included is helpful and lends itself to increased understanding.

Probably the most important conclusion this research can suggest is in the area of citizen participation. It appears evident from the profiles that citizen participation in the metro area is a political force which deserves recognition. The potential for reaction and pro-action are both great, although the non-urban areas tend to be less pro-action oriented. The experience being gained by citizens in organizing and participating is growing. Expertise in these groups is also growing. It is the conclusion of this researcher that citizen participation is becoming a sophisticated political force in Oregon.

A commonality which exists in areas with room for growth, is the issue of land use planning. Mostly because of the state land use law, this issue has been brought to public attention. This researcher would suggest that this issue and other such issues (planning, taxes, sewers, streets, etc.) which affect individual pocketbooks are more on the minds of the average citizen and community leader than are social problems of poverty, unemployment and delinquency. This suggests a tendency toward individualistic oriented values - values which are held firmly enough to make citizen participation a potent force.

As for social-economic levels, this research would conclude that, although there are areas of low income, concentrations of poverty are not apparent. A wide range of income levels exists. To be sure poverty does exist, and social problems related to poverty also exist. However, the perception of the general public is not such that these problems are very high in their awareness. 
Few conclusions can be made about the roles and inter-relationships of governmental bodies. This objective was unobtainable in light of the scope of the project. Feelings expressed concerning levels of government are present in the profiles. Generally this researcher concludes that people become more dissatisfied with government as it moves farther from their control and scrutiny. Not having the right to elect many positions is especially disliked by most of the population.

One of the objectives of this study was to show the personality of each community. It is the conclusion of this report that the personality of each community is as different as the individuals in those communities. A feeling for each community exists in each profile and it is felt that some of the personality of each area comes through.

Finally, it is the conclusion of this study that further research is necessary. Following are some recommendations in regards to further research and the use of the study.

\section{$\underline{\text { Recommendations }}$}

The following recommendations are those of this researcher and not necessarily those of the urban studies team.

In light of the presence of developing citizen participation, this report would recommend incorporation of citizen participation in planning prior to the public hearing phase. This might be accomplished at the local government level with Federal or State agencies providing needed technical assistance. Considering the frontier spirit of Oregon, without pro-active involvement of citizens, strong and adverse reaction will be a likely possibility in most project areas.

A second recommendation involves further study. This report recommends that an intensive literature survey be conducted on the social factors which contribute to community cohesion, identity, and citizen participation. Such factors as mobility, education, and employment should be examined as to their fect on the characteristics mentioned. It is also recommended that a comprehensive historical overview be done as part of any base of information concerning the metro area. Such an overview could help in understanding the development of different qualities of citizen participation, and community identity.

One last and probably the most important recommendation is for Federal agencies to take into account all social factors in planning. Even the most lowly individual and his rights should be taken into account. Change need not be made in long range objectives but until every last social factor, every person has been taken into account a true and honest assessment of social impact has not been made. An equally extensive cost-benefit analysis must be applied to social factors as well as economic. This alone is not enough. Inevitably there will be social costs in any project. The recommendation then is to anticipate those costs, through the social impact statement and then implement, either by referral or directservices, compensation for those affected. This might be accomplished by the establishment of citizen advisory boards. These boards would act as a vehicle of 
communications not only. advising the impact study team as to possible social affects but also enabling the community to plan for the inevitable social impacts. 


\section{APPENDIX I - MAPS}

1. Profile Area Map

2. Southeast Portland Neighborhoods

3. Northeast Portland Neighborhoods

4. North Portland Neighborhoods

5. Northwest Portland Neighborhoods

6. Southwest Port1and Neighborhoods 


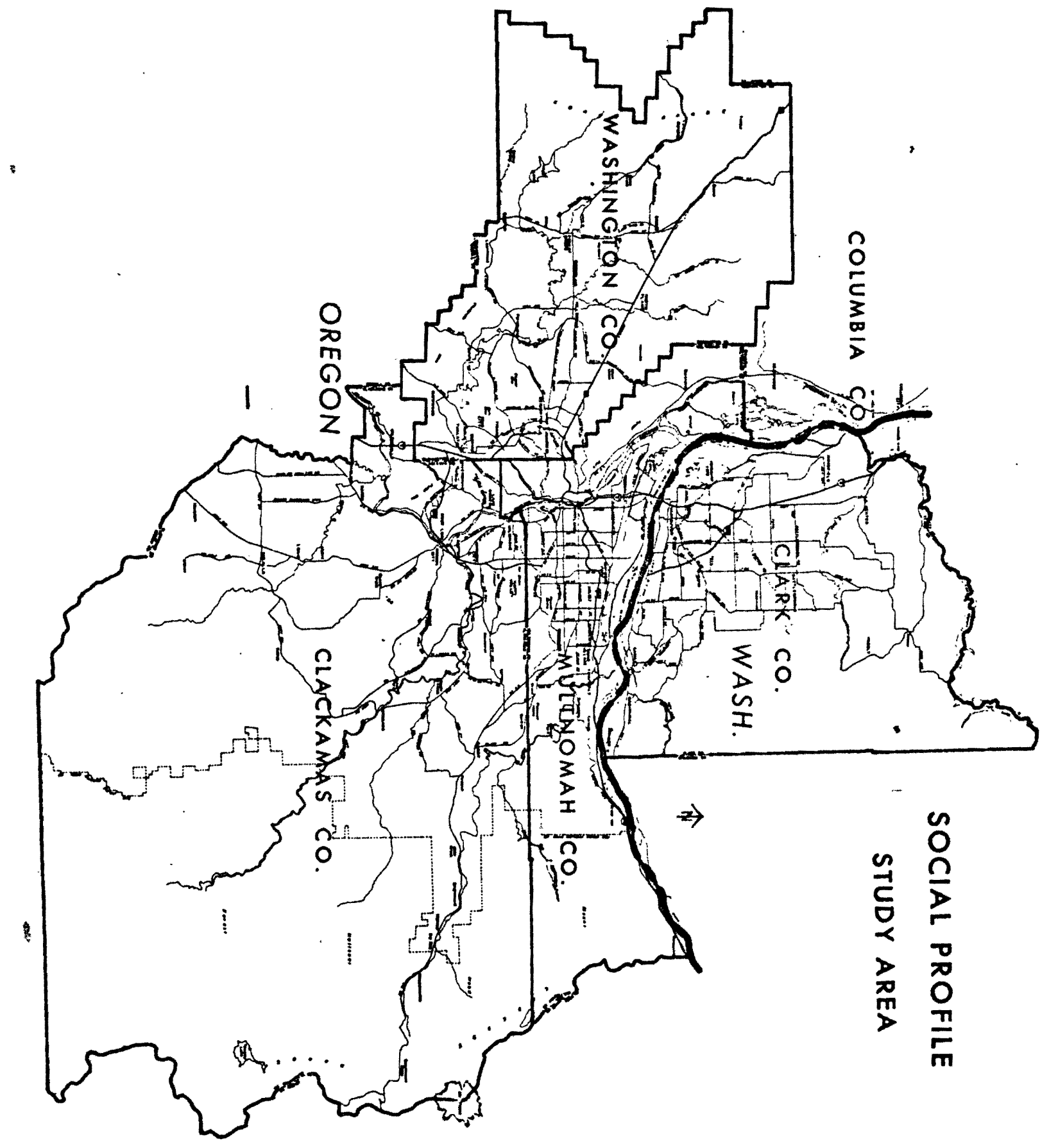




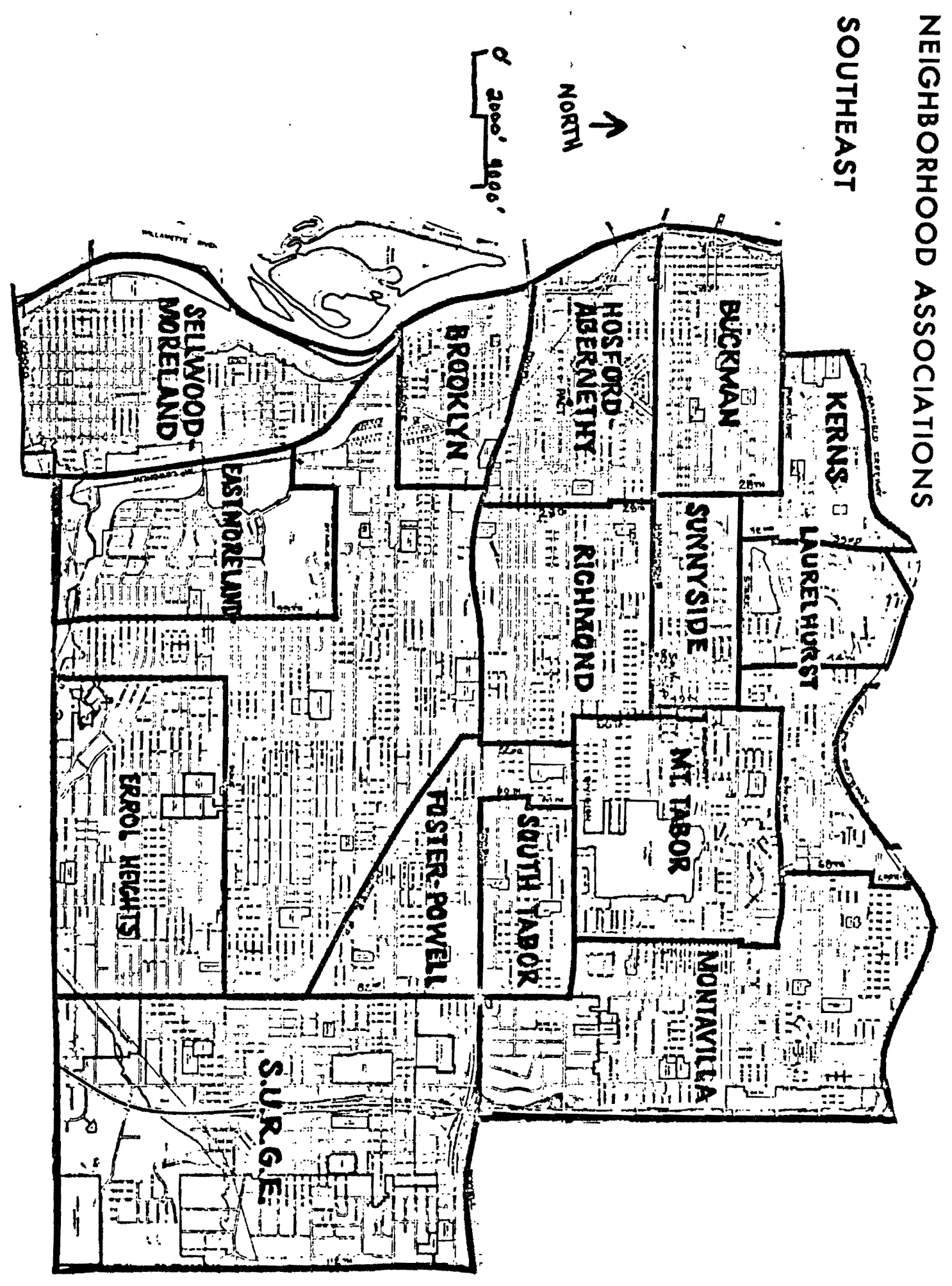


NEIGHBORHOOD ASSOCIATIONS

\author{
NORTHEAST
}

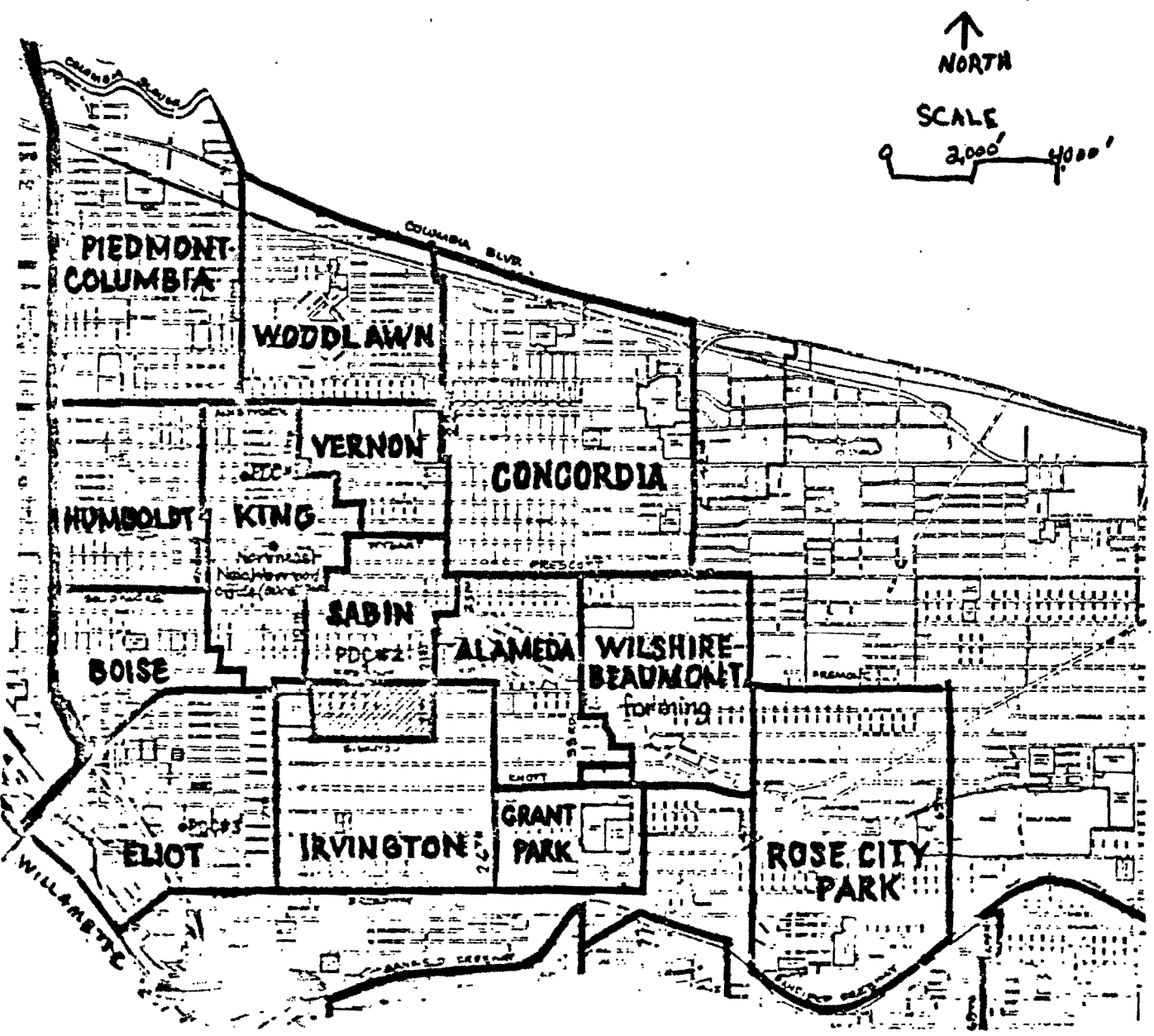




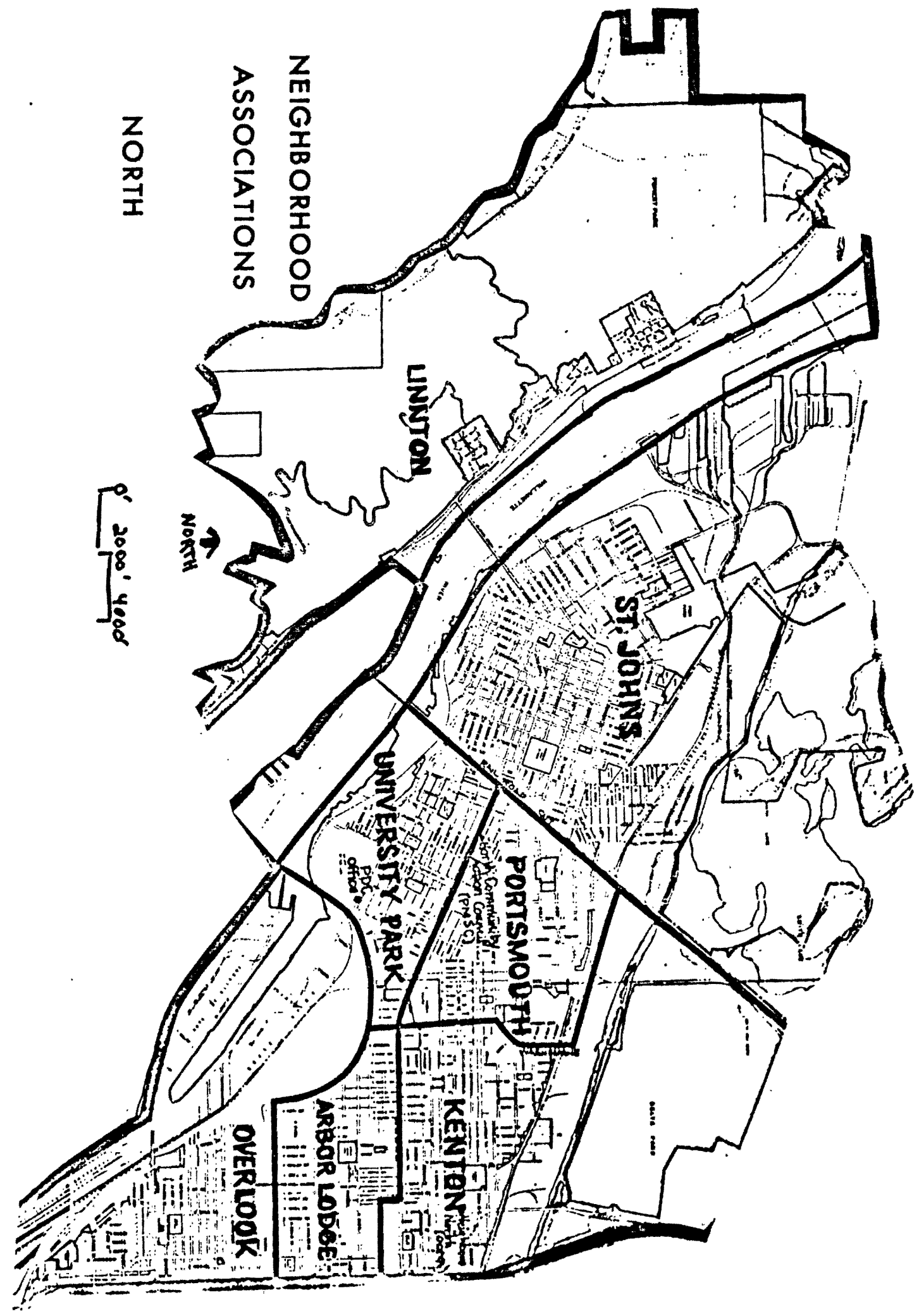




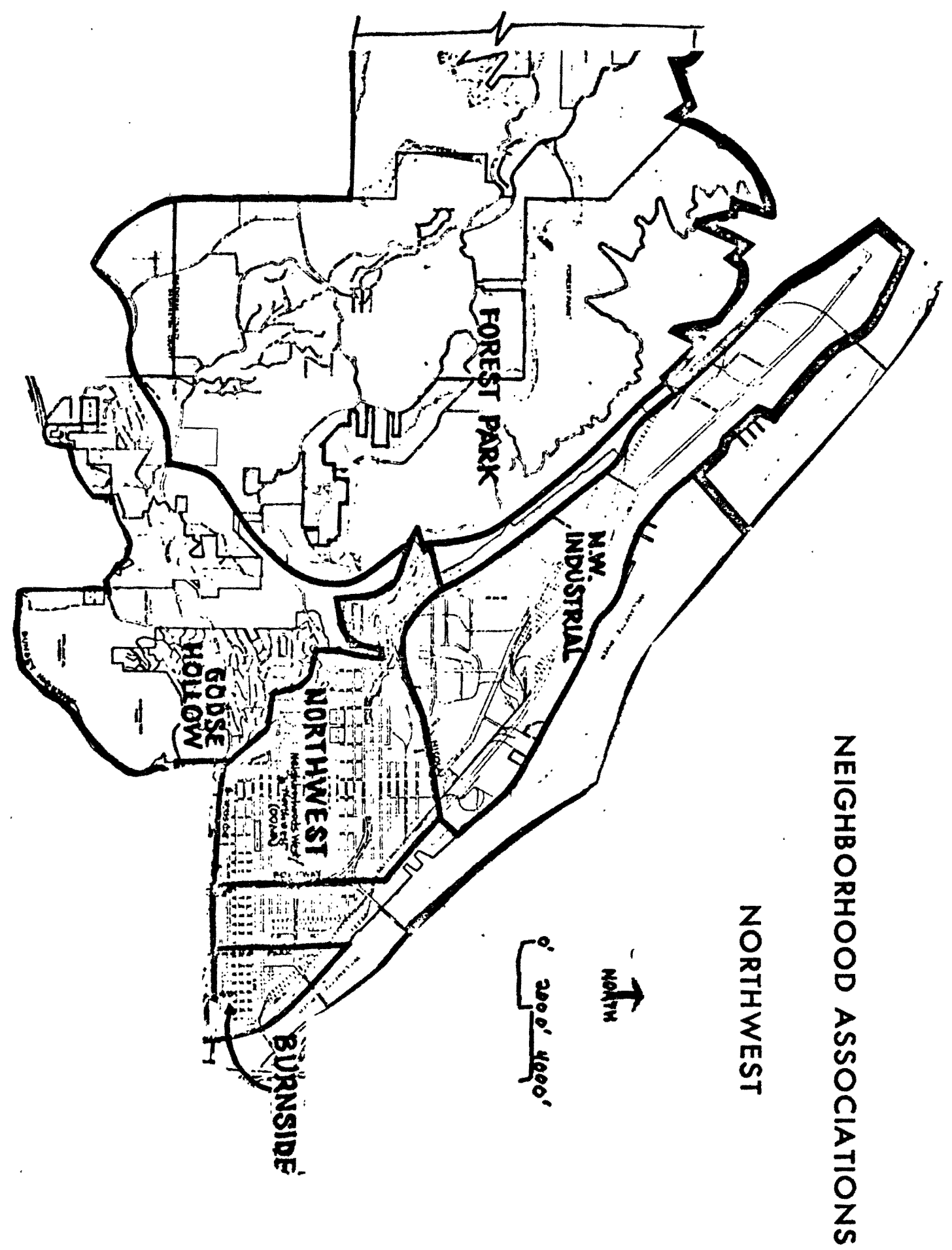




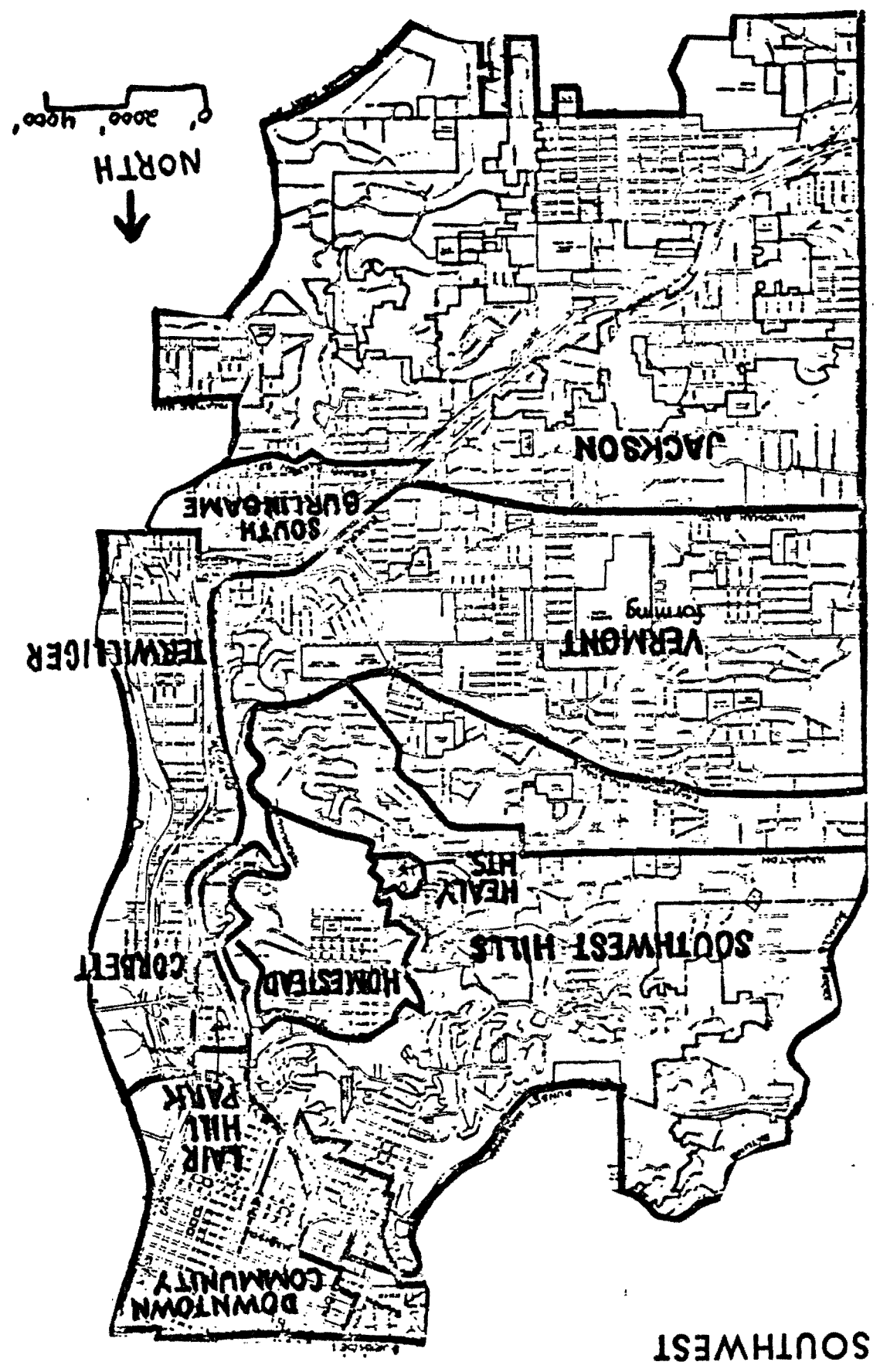

SNOIIVIJOSS OOOHУOЯHOIJN 


\section{APPENDIX II}

Resource Summary

In compiling this profile it became apparent that there were several sources of information both written and in the minds of individuals which might be found useful in further studies. The following is a summary of some of those resources.

1. Chamber of Commerce - Local chambers of commerce are one of the best sources of local data, giving the most concise and up-to-date material available. Especially helpful are statistical summaries.

2. Chinook Centrex - This local publication compiled by Ken Smith and Steve Johnson is an access directory for the City of Portland. Although done in 1973 it still is an excellent source listing interest groups and associations by name, address and phone. Especially helpful is the listing of professional, business, labor, cultural and ethnic associations.

3. Portland City Planning Bureau - This city agency has several research studies available and in process. Many of these such as an SMSA Housing study are available for a slight charge. Presently a population study is being conducted.

4. CRAG - Columbia Regional Association of Governments has available both written and non-written information on land use, planning, and citizen participation. CRAG is also helpful in directing one toward informed people at local levels.

5. Center for Urban Education (CUE) - This church-related center is an excellent source of information both from written studies and from talking to the staff. CUE periodically conducts workshops concerning urban affairs and publishes a bulletin.

6. Media - The Radio and Television media are required, for licensing purposes, to conduct attitudinal surveys of community leaders and the general population. The results of such studies are public information.

7. Multnomah County Planning Office - This office is currently involved in housing, land use and population studies. These studies appear to be in detail.

8. Portland Office of Neighborhood Assocations - This office has a great deal of information concerning specific neighborhoods. Also this office's 1975 annual report gives an excellent summary of neighborhood associations and their accomplishments. Neighborhood newsletters and paper are also good resources and information concerning them can be obtained from this office. 
9. Private and Public Enterprise - Several industrial enterprises in Portland have conducted labor studies. These studies show characteristics of the work force such as place of residence. Textronix and The Port of Portland are two enterprises with such studies.

Portland General Electric compiles information concerning each community it serves as a public service. These PGE profiles are useful statistical resources.

Taylor and Company, a mail marketing firm, and other such firms have up-to-date economic data concerning housing and income. They have this information available in color coded maps.

10. The Tri-County Local Government Commission - This study agency is one of the best sources of concise information on local government and citizen participation. They have available written reports and summaries of local governmental, structure, responsbilities and jurisdictions. In July 1977 this agency will publish a final report.

11. The Urban Atlas - This compilation of census information is beautifully displayed on large colored maps covering the Portland SMSA by tracts. Characteristics such as age, race, density and income are among the twelve displays.

12. Urban Studies Department, PSU - This Department of the University is involved in research in the Portland area. One of their recent projects is being prepared for publication. It is a study of sample neighborhood associations in Portland with a history and summary of each. This information will be available through the Tri County Local Government Commission. 
1. Degree of c1tizen involvement:

2. Issues:

\%

b. What people don't like to see:

$\dot{*} \cdot$

\section{a. What people like to see:}

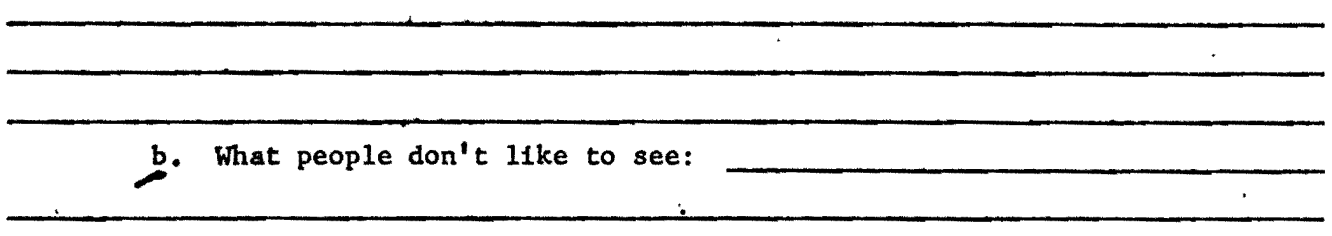

3. How people meet problems:

4. a. What does the area have going for $1 t$ ?

5. Are things getting better or worse?

\section{b. What does the area lack?}

\section{Occupational status:}

7. Role In Metro Area:

\section{Other:}


Anderson, Patricia and Farthing, Judith. Social Profile of Clark County. Vancouver, WA: Health and Welfare Council, July 1972.

Barber, James David. Citizen Politics. Chicago: Markham Publishing Co., 1969.

The Columbia. Special Edition, Heritage 1776 - 1976. Vancouver, WA., July 1976.

French, Robert Mi11, The Community:- A Comparative Perspective. Itasca I11: EE. Peacock Publishers Inc., 1969.

Freudenbery, Edward and Street, Lloyd. Social Profiles: Los Angeles Co. Los Angeles: Welfare Planning Council, Research Report, July 1965.

Hutchings, Nancy and Meyer, Alice. Portland in Your Pocket. Forest Grove, OR: Timber Press, 1976.

Love, Ruth. Forest Park Estate: A Social Impact Study. A non-published report. June 1973.

Media Statistics, Inc. Special Survey Report for FCC Renewal Application, Survey of General Public, Portland Oregon, 1974. Washington, D.C.: Media Statistics, 1974.

Merchants Exchange of Portland, OR. Foreign Exports Statistics, Portland, OR: 1974.

Minar, David W. and Greer, Scott, eds. The Concept of Community. Chicago: Adine Publishing, 1970.

Nordin, Dennis. Rich Harvest: A History of the Grange 1867-1900. Jackson, Mississippi: University of Mississippi Press, 1974

O'Donne11, Terence and Vaughan, Thomas. Portland: A Historical Sketch and Guide. Portland: Oregon Historical Society, 1976.

Oregon Office of Secretary of State. The Oregon Blue Book 1975-1976. Berylalee Winningham ed., Salem, OR: Office of Secretary of State, 1975.

Portland office of Neighborhood Associations. Citizen Participation in Portland, Oregon. 2nd Annual Report, Dec. 1975.

Scott, Edna Agnes. The Grange Movement in Oregon. University of Oregon Thesis, 1923. 
Selltiz, Claire; Johoda, Marie; Deutsch, Morton and Cook; Stuart W. Research Methods in Social Relations. San Francisco: Holt Rinehart \& Winston, 1959

Shipway, David. A Socio-Economic Profile of Western Oregon. Boulder, Co: Western Interstate Commission for Higher Education, 1975.

Tri-County Local Government Commissions. Phase I Reports. Portland, OR 1976.

Warren, Roland L. Perspectives on the American Community. 2nd ed. San Francisco: Rand McNally, 1973. 
This intern report was read and accepted by a staff member at:

Agency: U.S. Army Corps of Engineers

Address: Portland District

P.0. Box 2946

Portland OR 97208

This report was completed by a WICHE intern. This intern's project was part of the Resources Development Internship Program administered by the Western Interstate Commission for Higher Education (WICHE).

The purpose of the internship program is to bring organizations involved in community and economic development, environmental problems and the humanities together with institutions of higher education and their students in the West for the benefit of all.

For these organizations, the intern program provides the problemsolving talents of student manpower while making the resources of universities and colleges more available. For institutions of higher education, the program provides relevant field education for their students while building their capacity for problem-solving.

WICHE is an organization in the West uniquely suited for sponsoring such a program. It is an interstate agency formed by the thirteen western states for the specific purpose of relating the resources of higher education to the needs of western citizens. WICHE has been concerned with a broad range of community needs in the West for some time, insofar as they bear directly on the we1l-being of western peoples and the future of higher education in the West. WICHE feels that the internship program is one method for meeting its obligations within the thirteen western states. In its efforts to achieve these objectives, WICHE appreciates having received the generous support and assistance of the Economic Development Administration; the Jessie Smith Noyes Foundation; the National Endowment for the Humanities; the Wyoming Office of Manpower Planning; and of innumerable local leaders and community organizations, including the agency that sponsored this intern project.

For further information, write Bob Hullinghorst, Director, Resources Development Internship Program, WICHE, P.O. Drawer ' $P$ ', Boulder, Colorado 80302 or call (303) 492-7177. 